\title{
The Global Impact of Brexit Uncertainty*
}

\section{Tarek A. Hassan ${ }^{\dagger}$, Laurence van Lent ${ }^{\ddagger}$, Stephan Hollander ${ }^{\S}$, and Ahmed Tahoun}

\section{Working Paper No. 106}

January 10, 2020

\begin{abstract}
Using tools from computational linguistics, we construct new measures of the impact of Brexit on listed firms in the United States and around the world; these measures are based on the proportion of discussions in quarterly earnings conference calls on the costs, benefits, and risks

\footnotetext{
* For valuable comments, we thank Tom Ferguson, John van Reenen (discussant), Marcel Olbert, Xiang Zheng, Menghan Zhu and seminar participants at the 2020 American Economic Association Meetings, Banque de France, Boston University, Stanford, and Tilburg University. For excellent research assistance, we thank Aakash Kalyani, Adam Oppenheimer, and Markus Schwedeler. Tahoun sincerely appreciates continued support from the Institute for New Economic Thinking (INET). Van Lent gratefully acknowledges funding from the Deutsche Forschungsgemeinschaft Project ID 403041268 - TRR 266.

${ }^{\dagger}$ Boston University, NBER, and CEPR; Postal Address: 270 Bay State Road, Boston MA 02215, USA; E-mail: thassan@bu.edu.

¥ Frankfurt School of Finance and Management; Postal Address: Adickesallee 32-34, 60322 Frankfurt am Main, Germany; E-mail: 1.vanlent@fs.de

$\S$ Tilburg University; Postal Address: Warandelaan 2, 5037 AB Tilburg, the Netherlands; E-mail:

s.hollander@tilburguniversity.edu

'London Business School; Postal Address: Regent's Park, London NW1 4SA, United Kingdom; E- mail: atahoun@london.edu.

https://doi.org/10.36687/inetwp106
} 
associated with the UK's intention to leave the EU. We identify which firms expect to gain or lose from Brexit and which are most affected by Brexit uncertainty. We then estimate effects of the different types of Brexit exposure on firm-level outcomes. We find that the impact of Brexitrelated uncertainty extends far beyond British or even European firms; US and international firms most exposed to Brexit uncertainty lost a substantial fraction of their market value and have also reduced hiring and investment. In addition to Brexit uncertainty (the second moment), we find that international firms overwhelmingly expect negative direct effects from Brexit (the first moment) should it come to pass. Most prominently, firms expect difficulties from regulatory divergence, reduced labor mobility, limited trade access, and the costs of post-Brexit operational adjustments. Consistent with the predictions of canonical theory, this negative sentiment is recognized and priced in stock markets but has not yet significantly affected firm actions.

JEL Codes: D8, E22, E24, E32, E6, F0, G18, G32, G38, H32

Keywords: Brexit, uncertainty, sentiment, machine learning, cross-country effects 
Three years after the British electorate voted to leave the European Union, it is still uncertain how the economic relation between the EU and its former member country will evolve. While this persistent uncertainty clearly weighs on the minds of British voters (for example, witness Boris Johnson's pledge to "get Brexit done"), many commentators, business leaders, and politicians have also pointed to the high economic costs of this uncertainty. Some British and European leaders have even suggested that it might be preferable for the UK to leave the EU without a negotiated deal than to endure additional years of uncertainty. ${ }^{1}$

Indeed, corporate executives and stock-market participants around the world have had to consider a bewildering sequence of hard and soft Brexit proposals made by a succession of British prime ministers and question how each proposal might affect the corporate world, financial markets, and, ultimately, the economy. Their pressing question is how the prospect of Brexit and its related uncertainty affects firms' actions.

While economists have made some progress in estimating the direct and indirect effects of Brexit on UK-based firms, attempts to quantify the effect on and responses of firms outside the UK have proven more complicated. Indeed, the exposure of non-UK-based (international hereafter) firms to Brexit is hard to measure for at least three reasons. First, Brexit exposure can come from many potentially interdependent sources; these sources include barriers to product market access; frictions in managing relationships with customers, suppliers, and subsidiaries; and hurdles in expanding business. This means that any attempt to quantify Brexit exposure for an international firm may overlook economically meaningful but potentially indirect determinants. Second, exposure to Brexit is not a time-invariant trait. Indeed, the prolonged political process stemming from the 2016 referendum has yielded a sequence of potential negotiation outcomes, which each come with their own implications for a given firm. A firm might be a Brexit "winner" one day, only to be in a disadvantaged position the next. Thus, any proposed measure of exposure to a shock like Brexit (which varies substantially over time in both scope and potential outcome) needs to be able to track longitudinal

\footnotetext{
${ }^{1}$ Most notably, French President Emmanuel Macron has publicly taken this position (Waterfield et al. (2019) in The Times).
} 
impact while also accounting for cross-sectional variation. Third, in addition to the impact on uncertainty (second moment), exposure to Brexit also stems from Brexit's effect on expectations about the mean of firms' fortunes (first moment). Indeed, before Brexit (and the future relationship between the UK and the EU) is finalized and legislatively and administratively enacted, one might expect that most of the impact occurs through uncertainty, where mean effects are perhaps limited to firms' costly preparations for implementation and to precautionary measures that reduce impact. Ultimately, however, quantifying the first and second-moment effects of Brexit must be achieved empirically.

Our study addresses each of these challenges. We propose a general text-classification method for isolating first and second moment shocks stemming from specific events (Gentzkow et al., 2019; Hassan et al., 2019). Our approach identifies the exposure of firms to a given event (in this case, Brexit) by counting the number of times the event is mentioned in a given firm's (quarterly) earnings conference call with financial analysts. These calls usually happen in conjunction with an earnings release and are an opportunity for management to describe the current affairs of the company. Importantly, after the management's presentation, a Q\&A session is held during which analysts probe management on challenges the firm is facing. In this "market place" of information, we intuit that managers and analysts devote more time to events that are of greater importance to the firm, which makes the time spent discussing an event a powerful measure of a firm's exposure to it. Since call participants are arguably among the foremost experts on the firm's business, any significant impact of Brexit - through financial, product, and labor markets or otherwise - will likely come up in conversations. Concerns about missing the difficult-to-observe effects of Brexit on international firms are therefore plausibly mitigated. Thus, using these calls to measure Brexit exposure allows us to identify its market-assessed, over-time variation from the moment that talks of a Brexit referendum began (before 2016) until the present. Indeed, our method allows us to track any changes in firm-level Brexit exposure (due to, for example, developments in the EU-UK negotiations) and without the need to conduct surveys of ex- 
ecutives in multiple countries. Finally, we adapt the Hassan et al. (2019) (HHLT) method of measuring firm-level political risk and sentiment in order to bifurcate our overall measure of Brexit exposure into first (BrexitSentiment) and second-moment (BrexitRisk) scores. We determine whether call participants use "risk" or "uncertainty" synonyms near the term "Brexit" to measure BrexitRisk and use positive- and negative-tone words near "Brexit" to capture BrexitSentiment.

Using these newly constructed measures, we document a set of novel empirical findings on the impact of Brexit on firms in 71 countries. While these findings validate our Brexit exposure measures, they are also significant in their own right. For example, not only do we show that concerns about Brexit explode for UK firms in the most recent quarters of our sample period (extending to the second quarter of 2019 where a "no deal" Brexit became a real possibility), we also show widespread worries about Brexit-related risks among international firms. For instance, Irish firms on average discuss Brexit significantly more than do UK firms. Remarkably, Brexit exposure is strongly felt as far afield as the United States, South Africa, and Singapore.

It is also noteworthy that both UK and non-UK firms overwhelmingly expect negative consequences from Brexit. When we aggregate the Brexit sentiment up to the country level, there is no single country with a significantly positive average. Only in extraterritorial tax havens such as the UK Channel Islands and the British Virgin Islands is the average Brexit sentiment of local firms positive, though this is not statistically distinguishable from zero. Next, we conduct a human audit of text snippets from conference calls that mention Brexit in order to determine the content of the associated discussions. We find that firms mostly expect Brexit headwinds from regulatory divergence, reduced labor mobility, limited trade access, and heightened uncertainty.

There are some instances where firms articulate positive outlooks - in the most optimistic text snippets, managers expect little exposure to Brexit or expect windfalls from the Brexitinduced depreciation of the British Pound. Notably, we find little or no discussion about the 
major economic benefits touted by the Leave campaign (such as looser regulation or better trade deals), even for UK-based firms. ${ }^{2}$

We next examine how US and other international firms respond to Brexit exposure. Using our time-varying, firm-level measure, we show that Brexit exposure mostly affects firm-level actions through risk (rather than through sentiment); we document large, negative effects of BrexitRisk on investment and employment decisions as well as on contemporaneous stock returns. As an example, we estimate that due to Brexit risk, the average Irish firm decreased its investment rate by $3.9 \%$ and reduced its employment growth rate by $4.2 \%$ relative to the mean in every year since the Brexit referendum. For US-based firms (which are, on average, less exposed to Brexit than Irish firms), reductions in average investment and employment growth rates are $0.4 \%$ and $1.2 \%$, respectively.

We supplement these analyses with two key pieces of evidence. First, we investigate how stock markets reacted to information about the (surprising) outcome of the 2016 referendum. Pricing effects can stem from the effect of the Brexit vote on the expected discount rate or on the market's expectation of future cash flows (Gorbatikov et al., 2019). We disentangle these two sources and show that the mean of firm-level exposure to Brexit (i.e., BrexitSentiment) is positively associated with stock returns in a narrow event window around the date of the referendum, whereas the association with the variance of firm-level exposure (i.e., BrexitRisk) is significantly negative. In other words, both first- and second-moment exposure to Brexit is quickly incorporated into stock prices after the announcement of the referendum result.

Second, we examine whether the average Brexit exposure in a given UK district is associated with the share of that district's electorate who voted to leave the EU in 2016. Our findings show that constituents who live closer to the firms most negatively affected by Brexit tended to vote to remain in the EU. For example, a one-standard-deviation increase in the district-level Brexit risk is associated with a 1.4 percentage-point decrease in the proportion

\footnotetext{
${ }^{2}$ The Leave campaign focused on deregulation (from EU laws), new jobs in the UK, reduced UK contributions to the EU, and increased trade/exports from new trade agreements made on sovereign terms. See: http://www.voteleavetakecontrol.org/our_case.html
} 
of votes for leaving the EU.

Taking this evidence together, we conclude that up to this point, the Brexit vote has mostly acted as an uncertainty shock. While stock markets have recognized and priced both the expected effects on future cash flows and the discount rates, the first moment effects of Brexit have not yet been realized. So far, firms' real decisions have been a response to increased uncertainty, but not to the changes in the mean of their exposure to Brexit (i.e., whether the shock is good or bad news for the firm). In this sense, our analysis suggests that many of Brexit's effects have yet to materialize.

Related literature. Our paper builds on several strands of literature. We particularly rely on the literature on investment under uncertainty, which argues that any increase in risk should decrease a firm's investment and employment growth (e.g., Pindyck (1988); Bernanke (1983); Dixit and Pindyck (1994); Bloom et al. (2007)). ${ }^{3}$

A few studies have attempted to specifically quantify the impact of Brexit uncertainty. For example, Bloom et al. (2019) use a survey of decision makers in UK firms to measure Brexit-related uncertainty and its associated (negative) impact on investment and productivity. ${ }^{4}$ While we also show economically meaningful negative consequences for UK firms, we further add to these studies by highlighting the economic consequences of Brexit for non-UK firms, documenting the (potentially surprising) far-reaching global effects associated with this shock. ${ }^{5}$ Not only does our method allow us to explore the impact of exposure to Brexit across our sample, it also lets us disentangle the effect of Brexit on the variance (second moment) from its effect on the mean. In this way, we provide a deeper understanding of how

\footnotetext{
${ }^{3}$ In macroeconomic models, an increase in aggregate risk may increase or decrease aggregate investment due to general equilibrium effects on the interest rate (see, e.g., Fernández-Villaverde et al. (2015) and Hassan and Mertens (2017)). However, this ambiguity does not usually exist at the firm level (i.e., it is conditional on a time fixed effect). In models with adjustment costs, a firm facing a relative increase in firm-level risk should always decrease its investment as compared to other firms.

${ }^{4}$ Papers documenting a negative impact of Brexit on UK investments, employment, wages, trade, lending, and competition include Born et al. (2019); Berg et al. (2019); Van Reenen (2016); Sampson (2017); Breinlich et al. (2018); Davies and Studnicka (2018); Dhingra et al. (2017); Graziano et al. (2018); Garetto et al. (2019); Costa et al. (2019); McGrattan and Waddle (2017); Steinberg (2019).

${ }^{5}$ Campello et al. (2018) document the investment and hiring effects of Brexit on a sample of US firms exposed to the UK economy.
} 
cross-sectional variation in Brexit risk is linked with receiving (bad or good) news about the mean of the political shock, i.e., about Brexit's expected effect on future cash flows. While the ability to quantify firm-level Brexit exposure and to trace its development over time is valuable in its own right, our method also lets us use the source text of conference calls to better describe firms' concerns about Brexit at specific moments in time.

We also add to the important literature on the microeconomic effects of uncertainty (Bloom et al., 2018). While prior studies have shown that uncertainty has far-reaching consequences on firm policies of first order importance (such as investments and hiring), this work has been hampered by the lack of "sound, flexible measures of uncertainty" (Altig et al., 2019). Our work highlights the versatility of text-based measures of uncertainty, adding to recent work which pioneered these approaches in the context of political uncertainty (Baker et al., 2016; Hassan et al., 2019) and applied them to themes like trade policy (Handley and Li, 2018; Caldara et al., 2019; Kost, 2019).

Finally, our results also speak to the large international macroeconomics literature on the spillover of shocks across borders and on "contagion." A long-standing idea in this literature is that an uncertainty shock from one region can affect valuations and investment across the world (Forbes and Warnock, 2012; Rey, 2015). Our work shows a concrete and wellidentified example of such a spillover, where a shock originating in the UK affects valuations, investment, and other precautionary behavior in the United States and in other countries.

\section{DATA}

Our primary data are transcripts of quarterly earnings conference calls from publicly listed firms. From Refinitiv EIKON, we collect the complete set of 145,902 English-language transcripts from 2011 to 2019 from 7,733 firms headquartered in 71 countries. Firms host these calls in conjunction with their earnings announcements, allowing financial analysts and other market participants to ask questions about the firm's financial performance over the past quarter and to more broadly discuss current affairs with senior management (Hollander 
et al., 2010). ${ }^{6}$ Our data coverage, as shown in Table 1 Panel A, consists of 7,733 unique firms: 1,367 are headquartered in EU countries (396 in the UK), 3,791 are in the United States, and 2,575 are in the rest of the world. Panel B shows the extensive global coverage of listed firms in our sample. This coverage is important because Brexit exposure is not likely to be limited to firms headquartered in the UK or in adjacent countries; firms may have subsidiaries, suppliers, customers, competitors, or shareholders in the UK, or they may use UK facilities as a hub for hiring or communication. Of the roughly 3,800 US-based firms, 1,633 have disclosed establishments in the UK.

Financial statement data, which includes information on employment, investments, revenue, and earnings, are taken from the Standard and Poor's Compustat North America (US) and Compustat Global (non-US) files. Stock return information is from the Center for Research in Security Prices and Refinitiv Datastream. UK district voting results on the Brexit referendum (as well as basic demographic data on these districts) are from the Office for National Statistics.

\section{Measuring Firm-Level Brexit Exposure, Risk, and Sentiment}

To create a time-varying measure of a given firm's Brexit exposure, we parse the earnings call transcripts and count the number of times the word "Brexit" is used. We then divide this number by the total number of words in the transcript to account for differences in transcript length ${ }^{7}$

$$
\text { BrexitExposure }_{i t}=\frac{1}{B_{i t}} \sum_{b=1}^{B_{i t}} 1[b=\text { Brexit }]
$$

\footnotetext{
${ }^{6}$ As an alternative measure, we could have used firms' annual reports (10-K filing) as a text source (see, Campello et al. (2018)). We decided against this approach and follow HHLT, who document better measurement properties of firm-level risk measures using conference call transcripts instead of financial statements. Anecdotally, according to a Wall Street Journal report, the SEC Chairman Mr. Jay Clayton lamented that firms fail to sufficiently disclose the potential risk posed by Brexit (Shumsky, 2018). If this is true, relying on 10-Ks would underestimate a firm's exposure to the shock.

${ }^{7}$ Google Trends shows the first use of the term "Brexit" in October 2012. Usage of the word increased in January 2016 and peaked in June 2016. "Brixit" was proposed as an alternative term, but does not have a meaningful volume on Google Trends in the sample period.
} 
where $b=0,1, \ldots B_{i t}$ are the words contained in the call of firm $i$ in quarter $t .^{8}$

To construct a measure of Brexit risk, we augment this procedure by conditioning on the proximity to synonyms for risk or uncertainty:

$$
\text { BrexitRisk }_{i t}=\frac{1}{B_{i t}} \sum_{b=1}^{B_{i t}}\{1[b=\text { Brexit }] \times 1[|b-r|<10]\}
$$

where $r$ is the position of the nearest synonym of risk or uncertainty. Following the example of HHLT, we condition on a neighborhood of 10 words before and after the mention of Brexit and obtain a list of synonyms for "risk" and "uncertainty" from the Oxford English Dictionary. ${ }^{9}$ To aid interpretation, we standardize BrexitRisk by the average BrexitRisk for UK headquartered firms as measured in the period after the Brexit referendum (i.e., after the second quarter of 2016).

A major challenge in measuring risk is that innovations to the variance of shocks are likely correlated with innovations to the conditional mean. For example, a French exporter who learns that there may be future tariffs on her exports to the UK may conclude that she faces lower expected profits (a lower conditional mean) in addition to a higher variance (the tariffs may or may not materialize). Thus, teasing out the effects of Brexit-related uncertainty on a firm's actions also requires controlling for Brexit's effect on the conditional mean of the firm's future earnings. Thus, the construction of Brexit sentiment closely follows the procedure for BrexitRisk in that it counts the word Brexit; however, instead of conditioning on the proximity to words associated with risk, we condition on positive- or negative-tone words to capture the first moment. These positive and negative words are identified using the Loughran and McDonald (2011) sentiment dictionary.

$$
\text { BrexitSentiment }_{i t}=\frac{1}{B_{i t}} \sum_{b=1}^{B_{i t}}\left\{\left\{1[b=\text { Brexit }] \times\left(\sum_{c=b-10}^{b+10} S(c)\right)\right\}\right.
$$

\footnotetext{
${ }^{8}$ This procedure can easily be modified to obtain counts of variations on Brexit (e.g., "hard" or "soft" Brexit) and of other phrases that have become meaningful in the aftermath of the Brexit referendum (e.g., "no deal" or "WTO terms."

${ }^{9}$ See Appendix Table 1 for a list of these synonyms.
} 
where $S$ assigns sentiment to each $c$ :

$$
S(c)=\left\{\begin{array}{l}
+1 \text { if } c \in \mathbb{S}^{+} \\
-1 \text { if } c \in \mathbb{S}^{-} \\
0 \text { otherwise. }
\end{array}\right.
$$

Positive words include 'good,' 'strong,' 'great,' while negative include 'loss,' 'decline,' and 'difficult.' 10,11 Appendix Tables 2 and 3 show the most frequently used tone words in our corpus.

As for BrexitRisk, we standardize BrexitSentiment by the average BrexitSentiment for UK headquartered firms after 2016 Q2; a value of -1 denotes the average sentiment of UK firms after 2016.

For use in robustness checks and as control variables, we also measure each firm's nonBrexit-related risk and sentiment using the above approach, defining $\mathbb{R}$ as the set of synonyms for risk and uncertainty taken from the Oxford English Dictionary:

$$
\text { NonBrexitRisk }_{i t}=\frac{1}{B_{i t}} \sum_{b}^{B_{i t}}\{1[b \in \mathbb{R}]\}-\text { BrexitRisk }_{i t}
$$

and

$$
\text { NonBrexitSentiment } t_{i t}=\frac{1}{B_{i t}} \sum_{b}^{B_{i t}} S(b)-\text { BrexitSentiment }_{i t} .
$$

\footnotetext{
${ }^{10}$ We choose to sum across positive and negative sentiment words rather than simply conditioning on their presence to allow multiple positive words to outweigh the use of one negative word, and vice versa.

${ }^{11}$ One potential concern that has been raised with this kind of sentiment analysis is the use of negation, such as 'not good' or 'not terrible' (Loughran and McDonald (2016)). However, we have found that the use of such negation is exceedingly rare in our sample, so we chose not to complicate the construction of our measures by explicitly allowing for it.
} 


\section{VALidation}

\subsection{Global Exposure to Brexit}

In this section, we explore the properties of our measures, BrexitExposure, BrexitRisk, and BrexitSentiment, to corroborate that they capture firm-level variation in the global corporate response to Brexit. First, we show that firms' BrexitExposure is significantly correlated with observable business links to the UK. We then consider the constituent parts of BrexitExposure separately, describing (in detail) the patterns of both BrexitRisk and BrexitSentiment over time and across countries. To further validate our method, we present the results of a human audit of the text fragments (or "snippets") where Brexit is mentioned.

Exposure. Table 2 presents cross-sectional regressions of the mean BrexitExposure of each firm across time onto firm-specific characteristics that are ex ante likely to affect a firm's exposure to Brexit. In particular, we consider the geographical location of the firm's operational headquarters and establishments as well as the proportion of total (worldwide) sales earned in the UK. Because of the stickiness of firm location choice, we average the Brexit exposure of each firm across our sample from 2016 until the first quarter of 2019 and report robust standard errors. Table 2 Columns 1 and 2 only consider geographical location (and have a larger number of observations), while Columns 3 and 4 also include the proportion of UK sales. Across specifications, we find a positive association between mean BrexitExposure and a firm having a UK subsidiary. The estimated coefficient is about 0.2, implying that foreign firms with UK subsidiaries mention Brexit about one fifth as often as do firms headquartered in the UK. (Recall that our measure of Brexit exposure is normalized so that the average exposure of a UK firm during the 2016-2019 period is 1.) We find a similar positive association between a firm being headquartered in the UK and mean BrexitExposure, but the estimated coefficient is sensitive to including the proportion of UK sales revenues. We include two different proxies for UK revenues: the first is based on UK sales reported before the Brexit vote, while the second is based on the period after the 
vote. We also find that firms headquartered in the EU but outside the UK are more exposed to Brexit than firms headquartered internationally. Once more, this effect appears to be subsumed by post-referendum UK sales. Taken together, these findings are consistent with the notion that BrexitExposure varies meaningfully with firm characteristics that increase the probability of a firm being commercially connected to the UK.

Risk and Sentiment. Having offered evidence that supports the validity of BrexitExposure, we next explore the properties of BrexitRisk and BrexitSentiment. Figure 1 Panel A plots the across-firm average of BrexitRisk at each point in time for firms headquartered in the UK and for firms headquartered in the rest of the world. Consistent with the outcome of the 2016 referendum being a surprise to most parties, we find very low levels of BrexitRisk before 2016 in the UK (right) and in the rest of the world (left). BrexitRisk increases somewhat in the run up to the referendum in the first half of 2016. Non-UK firms' BrexitRisk peaks in the immediate aftermath of the referendum at about 0.8 ; in other words, immediately after the referendum, Brexit risk for international firms reaches almost the height of the average UK-firm Brexit risk in the 2016-2019 period. UK firms have a similar peak, with average BrexitRisk reaching over 1.5 immediately following the referendum. ${ }^{12}$ While BrexitRisk subsides in 2017, it rises sharply in the second half of 2018, nearly reaching 3 for UK firms (and about 0.5 for non-UK firms). This time-series pattern closely mimics the negotiation process between the EU and the UK, particularly at the end of 2018, where the specifics of the deal reached between Theresa May's government and the EU became increasingly clear, as did the difficulties of obtaining parliamentary approval for that deal. In 2019, at the end of our sample, the prospect of the UK leaving the EU without a deal (and resorting back to WTO trade terms) became more likely, consistent with the uncertainty about Brexit reaching unprecedented levels in the UK at that time.

Figure 2 shows the average BrexitRisk by firm-headquarters country for all countries with non-zero BrexitRisk and a minimum of five headquartered firms. Country level val-

\footnotetext{
${ }^{12}$ Fisman and Zitzewitz (2019) show a similar (aggregate) pattern for the period between July-December 2016 using their Brexit Long-Short Index based on the stock returns of equities.
} 
ues are calculated by taking the mean BrexitRisk for all firms headquartered in a given country and computing each firm's average BrexitRisk using all available post-2015 observations. Countries with zero country-level BrexitRisk include those far from the UK, such as Thailand, Nigeria, and Argentina; we also do not register any Brexit risk in some nearby countries including Portugal and the Czech Republic. By construction, the UK country-level BrexitRisk in this period equals unity. Perhaps the most dramatic takeaway from this figure is the position of Ireland with a country-level Brexit risk of 1.68, far greater than the Brexit risk of the average UK firm. ${ }^{13}$ (This difference is statistically significant. Standard errors are given in Appendix Table 4.) Distance to the UK matters, as other high-scoring countries include nearby France, the Netherlands, Belgium, and Denmark (all EU member states). The non-EU countries most affected by Brexit risk are South Africa, Switzerland, Singapore, and Australia. Many non-EU countries with relatively high Brexit risk scores have longstanding Commonwealth ties to the UK. On the other hand, the Channel Islands are not part of the Commmonwealth, the UK, or the EU, but are major offshore financial centers and tax havens. Their BrexitRisk falls between the UK's and Ireland's. In all, EU-member states appear to have higher country-level Brexit risk than do affected countries in other parts of the world. The BrexitRisk of the average US firm is 0.11 , around $10 \%$ of the average UK firm and similar to the average Italian firm.

In Figure 3, we plot the mean BrexitRisk by industry for both UK and non-UK headquartered firms. The mean industry BrexitRisk is computed by averaging all firms in a particular industry; we observe that in almost all industries (Health Services is an exception), the mean BrexitRisk is significantly larger in the UK than it is in non-UK countries. The difference between the UK and the rest of the world is particularly prominent in the Services and Finance, Insurance, and Real Estate industries.

\footnotetext{
${ }^{13}$ Interestingly, this finding mirrors the result in Garetto et al. (2019), which uses a model to quantify the total welfare effect of Brexit on EU economies. They find that the Brexit shock most reduces purchasing power (i.e., real income) in Ireland. More generally, the literature on geography and trade argues that market and supplier access to neighboring countries is most important for small economies (Redding and Venables, 2004).
} 
Finally, we tabulate and review text fragments centered at the moment when the conversation in the earnings call turns to Brexit and its associated risks. Table 3 reports excerpts of transcripts with the highest BrexitRisk among firms with the highest firm-level BrexitRisk. In Panel A, these excerpts are taken from UK companies such as Bellway, Millennium and Copthorne Hotels, and Endava, and are dated from 2016 to 2019. In all cases, a reading of the excerpts confirms that call participants are discussing risks associated with Brexit. For example, the July 2017 transcript of Berendsen Ltd. says that "Brexit raises any number of uncertainties for every single business." The transcript for the January 2019 call of SThree Plc. states that "there's also a lot of uncertainty around the UK and Brexit and that will affect most markets." Panel B shows snippets discussing Brexit from companies headquartered outside of the UK. The top scoring transcripts are from a range of countries and come from across the post-Brexit-referendum sample period. In all cases, reading the text confirms that the discussion centers on the Brexit-related uncertainty faced by the firm. For example, in October 2018 the Swedish firm Sweco claimed that "there is still an uncertainty when it comes to Brexit and some weakness in the real estate market." Similarly, during their January 2019 call, FBD Holdings in Ireland recorded that "our agri and agribusiness customers are very exposed to a hard Brexit."

We next repeat the same steps for BrexitSentiment; in Figure 1 Panel B, we start with a plot of the respective time series for UK and non-UK firms. ${ }^{14}$ For both UK and non-UK firms, BrexitSentiment is negative overall. We observe a sharp fall in sentiment immediately after the Brexit referendum (a phenomenon more pronounced in UK firms than in international firms) with sentiment scores reverting to slightly below zero for most of 2017. In 2018, the average BrexitSentiment drops sharply both in the UK and internationally (though again, the effect is especially pronounced in the UK) with the drop continuing well into 2019.

Figure 4 plots the mean BrexitSentiment by country. Overwhelmingly, sentiment in

\footnotetext{
${ }^{14}$ In the firm-year panel beginning in 2016, the correlation between BrexitRisk and BrexitSentiment is 0.16 .
} 
the UK and elsewhere remains negative. Ireland continues to have the strongest negative sentiment scores, even compared to the UK. However, firms from EU member states like Germany, Austria, Italy, Denmark, Sweden, and France also hold strong negative views about the impact of Brexit. The one anomalous area is the UK Channel Islands, where BrexitSentiment is hugely positive with a value of +2 (truncated in the figure to save space). Due to the limited number of firms based in the Channel Island (8), however, we lack statistical power to distinguish their BrexitSentiment from zero. (Appendix Table 4 gives standard errors.)

These findings raise the question of what specific concerns underlie this widespread aggregate negative sentiment. And for firms expecting to benefit from Brexit, what advantages do they perceive? We answer these questions by classifying excerpts from the top 100 positive and negative BrexitSentiment firms, reading 349 positive-sentiment excerpts (128 are specific enough to be classified) and 549 negative-sentiment fragments (162 have specific reasoning). We classify the perceived benefits and concerns into six categories each. These categories are chosen based on an initial reading of the text excerpts, but with an eye to the concerns and benefits raised by politicians and other pundits active in the public debate about Brexit. Turning first to excerpts that express positive sentiment about Brexit (in Table 4), we find that over 80 percent of positive excerpts in the UK and elsewhere mention that the firm is not exposed to (and therefore does not expect much of an impact from) Brexit. The next most commonly perceived benefit of Brexit is a weaker pound. A telling example comes from the transcript of Millennium and Copthorne Hotels, who "saw a spike in leisure occupancy after the Brexit referendum in June as tourists took advantage of the cheaper pound." About 20 percent of the positive excerpts from both UK and non-UK firms are classified in this category. The final positive sentiment for UK firms is connected with relocation opportunities (4.55 percent). Non-UK firms with positive sentiment about Brexit also highlight the benefits associated with higher government expenditures or better trade access. For example, the Frankfurt-based Deutsche Boerse AG considers a scenario in which 
Brexit negatively affects London as a center of business; they have "seen a number of firms announcing that Frankfurt would ultimately be their European hub" and can see "potential opportunity coming from Brexit." An analyst on the call of the Dutch firm ForFarmers thinks "Brexit could be beneficial for ForFarmers" and that it "might have a positive impact on [their] position in the UK."

Importantly, we did not find a single excerpt from UK-based firms referring to any of the three major potential economic upsides of Brexit touted during the Brexit referendum campaign: better trade deals, decreased regulation, and more flexibility in UK government spending.

As might be expected, some expected outcomes of Brexit are positive for certain firms but negative for others. Indeed, as tabulated in Table 4, worsening trade access and a weaker pound are reasons for the negative Brexit sentiment in 5.88 (26.21) and 47.06 (60.69) percent, respectively, of the snippets in (non-)UK firms. Fears about decreased trade access are particularly prominent for non-UK firms, as illustrated by the excerpt from the Irish budget airline Ryan Air Holdings: "if the UK is unable to negotiate access to the single market or open skies it may have implications for our three UK domestic routes." UK firms are more negative than non-UK firms about adjustment and transition costs, with about 18 percent of UK but only 0.69 percent of non-UK firms mentioning costs related to Brexit preparations. New and/or multiple regulatory regimes and labor market frictions appear in equal measure in excerpts for UK and non-UK firms (about 10 percent). For example, the Russian Yunipro expresses the hope that "for the implementation of the Brexit, reasonable solutions will be found that will preserve to a large extent the rules of the single market for energy." Falling consumer confidence, our final category, comes mostly from snippets from UK firms (5.88 percent as compared to 1.38 percent for non-UK firms).

Taking these findings together, the following picture emerges: In the UK, Brexit sentiment is negative and has precipitously declined since the last quarter of 2018. In that same period, average Brexit risk (which peaked after the 2016 referendum) has steeply increased, 
surpassing the risk measured immediately after the vote. Overwhelmingly, the firm-level negative sentiment in the UK stems from the weak pound, preparation costs for Brexit, and the possibility of multiple regulatory regimes post-Brexit. Even the vast majority of hopeful firms base their positive outlook on either their lack of exposure to Brexit or on the depreciation of the currency. On average, countries outside of the UK mirror the UK's time series pattern in risk and sentiment, albeit to a lesser extent. EU member states generally experience higher Brexit risk than do countries father afield and, with few exceptions, their sentiment is negative. ${ }^{15}$ At the firm-level, negative international Brexit sentiment centers mostly on the weak pound, concerns about trade access, and multiple regulatory regimes.

\subsection{Event Study: The Asset Market Effects of Brexit}

We turn next to the asset pricing implications of the June 23, 2016 referendum to leave the EU. The outcome of this vote was a complete surprise to most observers (Fisman and Zitzewitz, 2019); polling in the preceding months had persistently shown a "Remain" victory (Born et al., 2019). Famously, the British politician Boris Johnson, then one of the leading figures of the Leave campaign, went to bed resigned to losing the vote only to wake up to the sound of demonstrators protesting the vote's outcome at his private residence. ${ }^{16}$ The lack of anticipation of the outcome creates favorable conditions for an event study assessing the asset pricing effects of Brexit. When investors learned the referendum's outcome, they formed new expectations about the future of publicly listed firms. Stock price changes capture changes in investors' expectations about the direct and indirect consequences of Brexit for the cash flows of the firm and for its discount rate (Fisman, 2001; Hill et al., 2019; Davies and Studnicka, 2018). For this reason, we investigate the response of firms' equity prices to the Brexit vote; this response captures the market's assessment of a given firm's exposure to Brexit. Correlating the market's assessment with our measures of Brexit

\footnotetext{
${ }^{15}$ These findings are broadly consistent with Vandenbussche et al. (2019), who use a country-sector analysis to find substantial losses in value added and employment across the $27 \mathrm{EU}$ member states, though there is significant heterogeneity in effect size that corresponds to the country's position in the global value chain.

${ }^{16}$ ITV report on 24 June 2016.
} 
exposure also serves to validate our method.

Summary statistics. Table 5 presents the mean, median, and standard deviation of the variables used in our event study. In Columns 4 and 6, we also provide the mean and standard deviation of each variable for the subsamples of UK and non-UK firms. As before, our key variables of interest are Brexit exposure, risk, and sentiment. For the purpose of this analysis, we consider both the "average Brexit" and "pre-Brexit" Exposure, Risk, and Sentiment. Brexit variables are computed by averaging all available Brexit scores from 2016 to 2019, while pre-Brexit variables are based on the sample of earnings conference calls before June 23, 2016. Brexit exposure, risk and sentiment are larger (in absolute value) in the UK than internationally regardless of whether they are calculated before or after the Brexit vote. For example, the mean $\overline{\text { BrexitRisk }}$ in the full sample is 0.195 , but in the UK sample, the corresponding value is equal to 1 (by construction). Sentiment across our sample is on average negative. Median values of Brexit-related variables are zero, consistent with analysts and senior management discussing Brexit only when they expect that their firm may be impacted. Stock returns are calculated using a narrow window of four trading days starting on June 24 and ending on June 28, 2016 (since the referendum took place on a Thursday). ${ }^{17}$

Regression results. In Table 6, we present estimates of Ordinary Least Squares (OLS) regressions of the following form:

$$
r_{i}=\alpha_{0}+\delta_{j}+\delta_{c}+\beta \text { Brexit }_{i}+X_{i}^{\prime} \nu+\epsilon_{i}
$$

where $r_{i}$ is the four-trading-day return following the Brexit vote; $\delta_{j}$ and $\delta_{c}$ are industry and headquarter-country fixed effects, respectively, Brexit ${ }_{i}$ represents either $\overline{\text { BrexitExposure, }}$

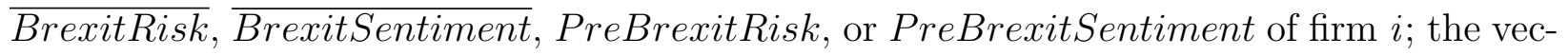
tor $X_{i, t}$ always includes the log of a firm's assets to control for firm size. In some specifica-

\footnotetext{
${ }^{17}$ We restrict the event study to firms with return data available on CRSP, i.e., to firms (cross)listed in the US.
} 
tions, we also include stock return betas, which are calculated by regressing daily returns in 2015 for firm $i$ on the S\&P500 or on the FTSE100 index (to measure a firm's exposure to the US and the UK capital markets, respectively). We exclude firms from the "Non Classifiable" sector and firms with fewer than ten earnings call transcripts.

In Columns 1 and 2 of Panel A (which reports the full sample estimates ${ }^{18}$ ), we find a negative coefficient estimate between $\overline{\text { BrexitExposure }}$ and asset prices. For a firm with a post-Brexit-vote exposure equal to that of the average UK-headquartered firm (i.e., with a value of 1 ), we find that equity prices drop by 2.6 percent over the course of the four trading days. The magnitude of the coefficient remains unchanged after controlling for the (US- and UK-market) CAPM-betas of the stock, implying that the effect is not explained by differences in exposure to US or UK market risk. We then "decompose" the Brexit exposure into a mean and variance component, i.e., we consider how markets priced differential exposure to $\overline{\text { BrexitRisk }}$ and $\overline{\text { BrexitSentiment }}$ in the short time window surrounding the announcement of the referendum result (Columns 3 and 4). We find that higher Brexit risk leads to lower stock returns $(\hat{\beta}=-0.011$, std. err. $=0.002)$, consistent with the event revising discount rates upward in the cross-section of firms. In addition to this effect of the second moment, we find that an increase in Brexit sentiment leads to higher stock prices $(\hat{\beta}=0.002$, std. err. $=0.001)$, consistent with the view that firms negatively exposed to Brexit lose significant market valuation immediately after the referendum results become known. Our coefficient estimates remain unaffected when we control for CAPM-betas (in Column 4).

In an effort to estimate the market's response using only the information available during the referendum, in the final column, we use the PreBrexitRisk and PreBrexitSentiment variables to explain the short window price response. In Column 5, we find a negative effect of PreBrexitRisk on the stock price change $(\hat{\beta}=-0.006$, std. err. $=0.002)$ However, we do not find a significant effect of PreBrexitSentiment on short window returns, though the sign and size of the coefficient is similar to those in prior columns.

\footnotetext{
${ }^{18}$ Note once more that the full sample consists of firms listed in the US. In Panel B, we restrict the sample to include only those firms who are both listed and headquartered in the US
} 
We repeat the same analysis in Panel B, but restrict the sample to firms headquartered in the United States. Our estimates for the US-headquartered sample do not deviate mean-

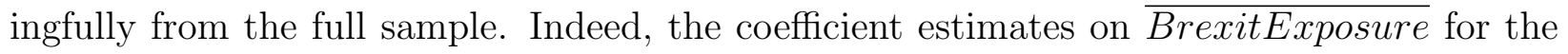
US-headquartered sample are only slightly smaller in Columns 1 and 2. When we tease out the two components of exposure to Brexit in Columns 3 and 4, we find a slightly stronger stock price response to $\overline{\text { BrexitSentiment }}$ and a somewhat weaker response to $\overline{\text { BrexitRisk }}$. Both are statistically significant at the one percent level. Finally, in Column 5, w find that for firms headuartered in the United States, Pre-BrexitSentiment and Pre-BrexitRisk are significantly positively associated with stock price changes (both at the five percent level).

We further examine the event study results in Figure 5, which graphically summarizes the OLS regression estimates of PreBrexitRisk (corresponding to Column 5 of Panel B in Table 6) onto a sequence of four-day return windows centered on the June 23, 2016 Brexit vote. Each event window consists of four consecutive trading days, where the "treatment" window stretches from June 24 to 28 and the remaining event windows are distributed in the periods before and after the treatment. As the referendum outcome was largely unexpected, we should not find a significant $\hat{\beta}$ before the vote. Similarly, if the effects of the leave vote are quickly reflected in asset prices, the effect should not linger after the vote. In line with these expectations, we find a significant negative coefficient estimate on PreBrexitRisk only during the treatment window, not before or after. These results bolster our confidence that the event-study estimates for Brexit risk are not inadvertently picking up some other factor/event. Importantly, the results also suggest that Brexit was not anticipated and that financial-market prices quickly reflected the news. ${ }^{19}$

Finally, in Figure 6, we estimate the asset pricing effect of the Brexit referendum separately for UK and non-UK firms. Indeed, the figure shows two panels of binned added-

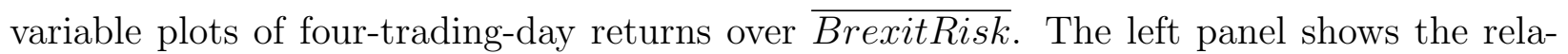

\footnotetext{
${ }^{19}$ Consistent with these results, Appendix Figure 1 shows the result of a placebo exercise where we re-run the same regression for each four-day window between Jan 12012 and Dec 31 2015. Reassuringly, we find only a slight tendency to over-reject the null.
} 
tion for the sample of UK-headquartered firms and the right panel shows the relation for non-UK-headquartered firms. The plots are again based on panel regressions that control

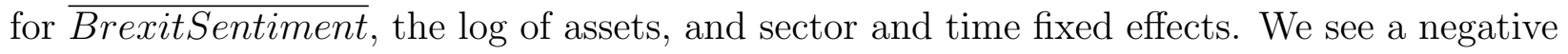
relation in both panels (although the slope coefficient is more negative in the UK sample), implying that the pricing response to Brexit uncertainty is negative for both UK and non-UK firms.

\subsection{Regional Support for Brexit}

The final empirical validation for our Brexit exposure measures builds on a simple intuition: When voters live in a region where a firm with elevated Brexit exposure is headquartered, they are more likely to vote against Brexit. Previous studies have generally focused on voter characteristics (such as age, ethnicity, and educational achievements) to explain geographical variation in voting (Alabrese et al., 2019; Fetzer, 2019). We propose that a voter's referendum choice will also be guided by their assessment of how Brexit will affect local economic and employment conditions. Thus, if local companies find Brexit risky, the regional share in support of "Leave" is likely to decrease. We test this intuition in Table 7.

We first determine each firm's location using the area code of its operational headquarters; we then map these locations into electoral districts. Next, we compute the district-level Brexit risk and sentiment by averaging $\overline{\text { BrexitRisk }_{i}}\left(\overline{\text { BrexitSentiment }_{i}}\right)$ across firms in the district. We then estimate cross-sectional regressions of the district-level vote in support of Leave $\left(\%\right.$ leave $\left._{c}\right)$ onto $\overline{\text { BrexitRisk }_{d}}, \overline{\text { BrexitdSentiment }_{d}}$, and two demographic controls (share UK born, i.e., the proportion of the districts' population born in the UK, and income per capita). Specifically,

$$
\text { \%leave }_{d}=\alpha+\beta \overline{\text { BrexitRisk }_{d}}+\gamma \overline{\text { BrexitSentiment }_{d}}+X_{d}^{\prime} \zeta+\epsilon_{d}
$$

These OLS regressions are estimated using data from 110 districts and their inferences are 
based on robust standard errors. Note that the distribution of sample firms in the UK is geographically clustered. Appendix Table 8 provides additional details. Many districts have only a single sample firm, but there are few districts in which many sample firms are headquartered (e.g., the City of London and Greater London).

In Column 1, where we only consider district-level $\overline{\text { BrexitRisk }}$, we find a negative association with the Leave vote share. Turning to $\overline{\text { BrexitSentiment }_{d}}$ in Column 2, we show that when firms in the district view Brexit negatively, the association with the Leave vote share is strongly negative. In Column 3, we include both Brexit variables and find results which are very similar to the separate estimates. The estimated coefficients imply that a one standard deviation increase in $\overline{\text { BrexitRisk }_{d}}(1.59)$ is associated with 1.48 percentage point decrease in share of the vote for leaving the EU. Similarly, a one standard deviation decrease in $\overline{\text { BrexitSentiment }_{d}}(4.44)$ is related to a 1.71 percentage point drop in support for Brexit. ${ }^{20}$ Figure 7 shows this association graphically. For completeness, note that wealthier districts and districts with a larger immigrant population have lower support for Leave.

These findings support the effort to validate our Brexit measures. However, they also speak to Alabrese et al. (2019) and Fetzer (2019), who find substantial geographical heterogeneity in the extent to which demographic variables can explain the Brexit vote. Our findings suggest that "spillovers" from local companies might be a partial source of this geographical heterogeneity.

\section{The Firm-Level Effects of Brexit}

Two substantive facts emerge from the validation exercise in the previous section. First, firms are exposed to the shock of the Brexit referendum, not just in the UK, but globally; though the shock is perhaps strongest in the (nearby) EU countries, it extends as far as the United States, Singapore, and South Africa. Second, stock markets quickly impound both the first and second moment implications in asset prices; increases in Brexit risk lead to

\footnotetext{
${ }^{20}$ The partial $R^{2}$ of these two variables in Column 3 is about $5 \%$.
} 
price drops while increases in Brexit sentiment (implying that Brexit is viewed positively) lead to price gains in a tight window around the 2016 referendum. While these findings are consistent with the forward-looking properties of equity markets, they also leave open the question of the degree to which individual firms respond to the Brexit referendum shock. We therefore estimate the effect of firm-level Brexit risk and sentiment on investments, hiring, and sales using the following specification:

$$
y_{i, t+1}=\delta_{j}+\delta_{t}+\delta_{c}+\beta \text { BrexitRisk }_{i, t}+\theta \text { BrexitSentiment }_{i, t}+X_{i, t}^{\prime} \zeta+\epsilon_{i, t}
$$

where $y_{i, t}$ is the firm-level outcome of interest; $\delta_{j}, \delta_{t}$, and $\delta_{c}$ are industry, year, and headquartercountry fixed effects, respectively; and where the vector $X_{i, t}$ always includes the log of the firm's assets to control for firm size, NonBrexit Risk, and NonBrexit Sentiment. BrexitRisk and BrexitSentiment are computed annually by averaging all available earnings call transcripts in a given year. Inferences are based on standard errors clustered at the firm-level. Firm outcomes are measured yearly from 2011 to 2018. Summary statistics on all firm-level variables are presented in Table 5 .

It is well-recognized in both theoretical and empirical work that uncertainty can directly influence firm-level investments and employment (Pindyck, 1988; Bernanke, 1983; Dixit and Pindyck, 1994; Bloom et al., 2007). Furthermore, recent developments in the literature have highlighted that first and second moment shocks can appear together, either amplifying or confounding each other (Bloom et al., 2018; Berger et al., 2017; Hassan et al., 2019). We examine these predictions in the context of Brexit, which (it has been argued) represents an "almost ideal" uncertainty shock inasmuch as it was large, unanticipated, and delayed in implementation (Fisman and Zitzewitz, 2019; Born et al., 2019). ${ }^{21}$

Figure 8 shows a binned added-variable plot of firm-level capital investment $\left(I_{i, t+1} / K_{i, t}\right)$

\footnotetext{
${ }^{21}$ Bloom et al. (2019) points out that Brexit presents a persistent uncertainty shock that should have a heterogeneous impact on UK firms; the impact depends on firms' prior exposure to the EU. Moving beyond the impact on UK firms, however, we are also able to estimate the effects of this shock on non-UK firms generally or on US firms specifically.
} 
over BrexitRisk $k_{i, t}$ while controlling for BrexitSentiment ${ }_{i, t}$, the log of assets, and sector and time fixed effects. The red (blue) line represents the slope estimate for the sample of UK (international) firms. In both panels, BrexitRisk $k_{i, t}$ is negatively and significantly associated with the capital investment rate. In fact, the estimated coefficients are very similar in magnitude: -0.609 (s.e. $=0.011)$ in the UK and $-0.670($ s.e. $=0.001)$ in the non-UK sample. The latter coefficient implies that for each year after 2016, an international firm with a BrexitRisk equal to that of the average UK firm experienced a $2.6 \%$ decrease in its investment rate relative to the mean (24.5).

In Table 8, we conduct a more systematic analysis of the relation between a firm's capital investment rate and Brexit risk and sentiment. In Panel A, we consider the full sample of UK and international firms. Column 1 presents estimates of a base specification with BrexitRisk $_{i, t}$ and BrexitSentiment ${ }_{i, t}$ (our variables of interest), time and sector fixed effects, and the log of assets as controls. As expected, we find a significant negative association between BrexitRisk $_{i, t}$ and the capital investment rate $(\hat{\theta}=-0.843$, std. err.=0.175). However, we find no significant association between BrexitSentiment $t_{i, t}$ and $I_{i, t+1} / K_{i, t}$. Next, we add an interaction term between BrexitRisk $k_{i, t}$ and an indicator variable that takes the value of unity when the firm is headquartered in the UK (zero otherwise) in order to explore whether the relation between uncertainty and investment is different for UK and non-UK firms. ${ }^{22}$ Consistent with the evidence in Figure 8, however, we find no statistically reliable evidence for such a difference. Specifically, with a comparable exposure to Brexit risk, the elasticity of investment with respect to Brexit risk is not significantly different for UK and international firms.

In the next three columns, we work towards our preferred specification by adding sectorby-time and country fixed effects (Column 3) and controls for the firm's overall (i.e., nonBrexit related) risk and sentiment (Columns 4 and 5, respectively). Reassuringly, we find that firms exposed to more overall uncertainty (calculated based on textual analysis of their

\footnotetext{
${ }^{22}$ As expected, the main effect of a given firm being headquartered in the UK is negative (-3.63, s.e. $\left.=0.808\right)$. For brevity, we suppress details in the table.
} 
earnings call as outlined in section 2) have lower investment rates. Similarly, firms that have more good news (measured using our earnings-call based measure of sentiment) have higher investment rates. Turning to our variables of interest, we find that our earlier conclusions regarding Brexit-related risk and sentiment are unchanged when we include these additional controls. We continue to find a negative association between BrexitRisk $k_{i, t}$ and investments, with only a minor attenuation of the estimated coefficient. Indeed, the estimated effect of

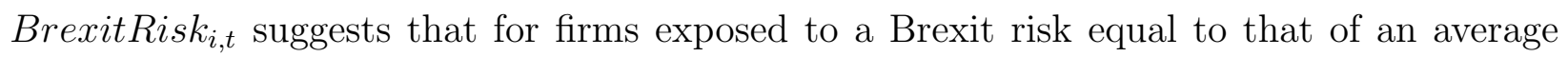
post-referendum UK firm (1), investments decrease by 0.640 percentage points (or 2.6 percent relative to the mean).

Extrapolating from the country-specific means in Figure 2, the estimate in Column 5 implies a $0.64 \times 1.86 / 27.52 \times 100=3.91$ percent decrease in the investment rate for the average Irish firm and a $0.64 \times 0.60 / 18.63 \times 100=1.99$ percent decrease for the average South African firm in our sample. Appendix Table 4 repeats this calculation to give the specific estimated impact of Brexit risk for each country shown in Figure 2.

As for the full sample, so for the sub-sample of firms headquartered in the US. In Panel $\mathrm{B}$, we repeat the same sequence of specifications as in Panel A but report only the coefficient estimates on BrexitRisk ${ }_{i, t}$ to save space. Our estimates for US firms are somewhat larger than in the full sample, potentially because firm-level variables are measured with less error in this more homogeneous sub-sample. Our preferred estimate in Column $5(-1.026$, s.e. $=0.346)$ suggests that Brexit risk accounts for a $0.37 \%$ decrease in the investment rate of the average US-based firm in each year after 2016.

Despite the rich set of controls included in the standard specification in Column 5, there are three remaining concerns with the interpretation of our results. First, executives might use Brexit and Brexit risk as an excuse to justify bad performance, even if their firm is not really exposed to the shock. The correlation between our measure BrexitRisk and the decline in investment might then be spurious, picking up "cheap talk" about Brexit. However, we have already seen that introducing controls for the firm's Brexit and overall (non-Brexit 
related) sentiment has no perceptible effects on our coefficient of interest (compare Columns 4 and 5 of Table 8). In Columns 2 and 3 of Table 9, we also add controls for the firm's recent performance. All specifications in this table include our standard controls, but for brevity show only the coefficients on Brexit risk and the newly added controls. Column 2 adds a measure for the firm's earnings surprise and Column 3 adds the firm's contemporaneous stock return, since bad performance should correlate with lower earnings and lower contemporaneous stock returns. Although the latter is arguably endogenous to Brexit's effect, neither of the two controls significantly attenuate the coefficient of interest, bolstering our confidence that our estimates are not driven by cheap talk.

The second concern with our results is that firms affected by Brexit risk might also be disproportionately affected by other types of risk. Again, controlling for non-Brexit-related discussions of risk and uncertainty had no perceptible effect on our estimates (compare Columns 3 and 4 of Table 8), demonstrating that the reduction in investment we document is specific to Brexit-related risk. Furthermore, Column 4 of Table 9 also controls for the firm's exposure to trade policy risk (PRiskTrade $i t)$. This variable (developed in HHLT) is constructed in the same way as BrexitRisk, but counts synonyms of risk or uncertainty near words that indicate a discussion of political decisions about trade policy. As expected, we find that exposure to trade-policy risk lowers the firm's investment rate (a one standard deviation increase in PRiskTrade $i t$ is associated with a 0.402 (s.e. $=0.209)$ percentage point decrease in that firm's investment rate). However, including this control has essentially no effect on our coefficient of interest, which remains stable at -0.692 (s.e.=0.186).

The third and final concern with our results is that UK-exposed international firms may be systematically different and may generally invest less than do other firms. To address this concern, Column 5 adds a firm's average sales in the UK before the Brexit referendum as a control variable. Column 6 further adds a firm-level, time-invariant measure of Brexit exposure that is calculated using all observations of a given firm in the sample $\left(\overline{\text { BrexitExposure }_{i}}\right)$. Note that both of these variables are "bad controls" (Angrist and Pischke, 2008) inasmuch 
as they are potential proxies for Brexit-related risk and/or sentiment and might therefore inappropriately reduce the explanatory power of our variables of interest. Despite these econometric concerns, we find little evidence that adding these additional controls changes the tenor of our main findings. Neither the pre-Brexit UK sales nor $\left(\overline{\text { BrexitExposure }_{i}}\right)$ are significantly associated with the investment rate. Furthermore, the significance of the estimated coefficient on BrexitRisk $k_{i, t}$ is not affected by their inclusion. Figure 9 shows the results of a placebo exercise where we re-estimate our standard specification in Column 5 of Table 8, but erroneously assign each firm's BrexitRisk to a three-year period prior to 2016. The first coefficient shows the results when we assign each firm's BrexitRisk to the years from 2011 to 2013. The second repeats the exercise for the years 2013 to 2015 . Comfortingly, point estimates are close to zero, and we find no statistically significant effect of Brexit risk prior to 2016. For comparison, the third coefficient shows the actual Brexit risk from our standard specification. Taken together, these results bolster our confidence that our estimates do indeed capture the causal effect of Brexit risk on firm-level investment.

Having established a consistent negative association between Brexit risk (though not sentiment) and the capital investment rate, we now turn to firms' employment and sales growth. In Table 10, we report panel regressions that correspond to our preferred specification in Column 5 of Table 8, both with and without the full set of fixed effects. In all of these regressions, we provide estimates based on the full sample, and, separately, our sample of US firms.

Prior work on the economic consequences of uncertainty suggests that hiring and investment should respond similarly to rises in uncertainty since both activities are associated with adjustment costs. In line with these predictions, Panel A in Table 10 shows (across both samples) a significant negative association between BrexitRisk $_{i, t}$ and employment growth $\Delta e m p_{i, t} / e m p_{i, t-1}$. Our preferred coefficient estimates are -0.391 (std. err. $\left.=0.179\right)$ and -1.272 (std. err. $=0.460)$ for the full sample and for the US, respectively, where the point estimate for US-based firms remains larger than the one for the full sample. The former estimate 
implies that a firm with the average Brexit risk of a UK-based firm experiences a decrease in its employment growth of $4.5 \%$ relative to the sample mean. (Appendix Table 4 breaks these numbers down by individual country.) As for the capital investment rate, we find no evidence of a significant association between BrexitSentiment $t_{i, t}$ and employment growth. As before, the coefficients on NonBrexitRisk and NonBrexitSentiment are statistically significant and have the predicted sign (see Appendix Table 6 for details and additional robustness checks).

Finally, we consider sales growth in Panel B. While we still find a negative relation between BrexitRisk $k_{i, t}$ and sales growth in all sample partitions, the association is no longer significant. This is consistent with the predictions of the real options literature, which postulates a larger short-run effect of risk on hard-to-reverse investments in physical and human capital than on short-run sales growth. In sharp contrast, however, and consistent with sales responding more directly to both good and bad news events, we find a positive and significant coefficient estimate between BrexitSentiment $t_{i, t}$ and sales growth. These first moment effects are again larger in the US sample, where our estimated coefficient of 0.410 (std. err. $=0.167)$ implies that firms with Brexit sentiment equal to that of the average UK firm after the referendum vote $(-1)$ have 0.41 percentage point lower sales growth in each year after 2016. Appendix Table 7 shows additional variations and robustness checks.

In Table 11, we examine the timing of the effect of Brexit risk on investment and employment outcome variables. We regress both the capital investment rate and the employment growth rate onto contemporaneous BrexitRisk $k_{i, t}$ and onto one-period-lagged BrexitRisk $k_{i, t-1}$. We find that employment responds more quickly than investment to changes in Brexit risk. Indeed, firm hiring responds more to concurrent than to lagged Brexit risk, while the opposite is true for the investment rate. 


\section{CONCLUSION}

Assessing the economic impact of specific policy measures, reforms, and other shocks requires measuring how these events affect the calculations and expectations of decision makers. In this paper, we develop a simple and adaptable text-based method to measure the costs, benefits, and risks that thousands of international decision makers associate with specific events. Our method offers several helpful features that address some of the challenges identified in recent research. First, it measures perceptions directly and in real time without conducting expensive large-scale surveys. Second, it meaningfully distinguishes between the perceived risks, costs, and opportunities associated with a given event, thus separating variation in first and second moments stemming from the event. This is particularly interesting in the context of Brexit, where policymakers have long pointed to the potentially detrimental effects of Brexit-related uncertainty, which we quantify directly. Third, many shocks do not (fully) play out in a short period of time, but present persistent challenges to economic actors. A method allowing researchers to measure over-time variation in a firm's exposure to a persistent shock is particularly valuable in light of recent evidence that the response to a persistent shock might be very different from the response to a shock that quickly fades away (Bloom et al., 2019).

We use our method to assess the extent to which international firms are affected by the outcome of the 2016 Brexit referendum. Our measures of Brexit exposure, risk, and sentiment behave in economically meaningful ways, strengthening our validity claims. In the process, we also document that firms inside and outside of the UK overwhelmingly view Brexit as "bad news." There are significant cross-country differences in Brexit risk: Ireland's Brexit risk is larger even than the UK's; nearby EU countries experience the strongest increase in risk; and Brexit risk also has a material (though weaker) impact in the United States and

other non-EU countries. Within the UK, we observe that geographical variation in the vote share for Brexit is correlated with the Brexit exposure of local firms (i.e., firms in the same 
electoral district).

When examining the earnings call discussions of individual firms, we find that even "Brexit winners" most often simply point out that they are currently not much affected by the prospect of Brexit. Those who see Brexit as negative, however, expect concrete difficulties for their businesses as a result of regulatory divergence, reduced labor mobility, decreased trade access, and post-Brexit operational adjustment. Indeed, when we examine how executives adjust firm policies in the face of rising Brexit uncertainty, we find consistently lower investment rates and reduced hiring. We also find that asset markets quickly impound both the future cash flow consequences of the Brexit vote and its impact on the discount rate; Brexit sentiment and Brexit risk both partially explain the pricing response on equity markets in the days following the referendum.

A casual reading of our findings might lead the reader to conclude that a speedy resolution of Brexit uncertainty is necessary to minimize harmful effects on the economy. Indeed, our empirical evidence does show that firms are cutting investments and hiring in the face of high Brexit uncertainty; resolution of this uncertainty could possibly return firms back to their normal policies. This, however, depends crucially on the way in which Brexit is resolved. Financial markets' pricing response to the Brexit vote does not only anticipate the negative effects of uncertainty, but also the direct negative effects of Brexit itself. Our reading of the evidence suggests that the greater the rupture between the UK and the EU, the larger these direct effects (including post-Brexit adjustment costs) will be. When Brexit is enacted, the consequences for investments and employment may well be larger than those associated with Brexit uncertainty alone. 


\section{REFERENCES}

Alabrese, E., S. O. Becker, T. Fetzer, and D. Novy (2019). Who voted for Brexit? Individual and regional data combined. European Journal of Political Economy 56, 132 - 150.

Altig, D., J. M. Barrero, N. Bloom, S. J. Davis, B. H. Meyer, and N. Parker (2019, June). Surveying business uncertainty. Working Paper 25956, National Bureau of Economic Research.

Angrist, J. D. and J.-S. Pischke (2008). Mostly harmless econometrics: An empiricist's companion. Princeton university press.

Baker, S. R., N. Bloom, and S. J. Davis (2016). Measuring economic policy uncertainty. The Quarterly Journal of Economics 131(4), 1593-1636.

Berg, T., A. Saunders, L. Schäfer, and S. Steffen (2019). 'Brexit' and the contraction of syndicated lending. Available at SSRN 2874724.

Berger, D., I. Dew-Becker, and S. Giglio (2017). Uncertainty shocks as second-moment news shocks.

Bernanke, B. S. (1983). Irreversibility, uncertainty, and cyclical investment. Quarterly Journal of Economics 98, 85-106.

Bloom, N., S. Bond, and J. Van Reenen (2007). Uncertainty and investment dynamics. Review of Economic Studies 74, 391-415.

Bloom, N., P. Bunn, S. Chen, P. Mizen, P. Smietanka, and G. Thwaites (2019, September). The impact of Brexit on UK firms. Working Paper 26218, National Bureau of Economic Research.

Bloom, N., M. Floetotto, N. Jaimovich, I. Saporta-Eksten, and S. Terry (2018). Really uncertain business cycles. Econometrica 86, 1031-1065.

Born, B., G. Mueller, M. Schularick, and P. Sedláček (2019). The costs of economic nationalism: Evidence from the Brexit experiment. The Economic Journal 129(10), 2722-2744.

Breinlich, H., E. Leromain, D. Novy, T. Sampson, and A. Usman (2018). The economic effects of Brexit: Evidence from the stock market. Fiscal Studies 39(4), 581-623.

Caldara, D., M. Iacoviello, P. Molligo, A. Prestipino, and A. Raffo (2019). The economic effects of trade policy uncertainty. Journal of Monetary Economics.

Campello, M., G. Cortes, F. d'Almeida, and G. Kankanhalli (2018). Exporting uncertainty: The impact of Brexit on corporate America. Available at SSRN 3078220.

Costa, R., S. Dhingra, and S. Machin (2019). Trade and worker deskilling. Working paper, National Bureau of Economic Research.

Davies, R. B. and Z. Studnicka (2018). The heterogeneous impact of Brexit: Early indications from the FTSE. European Economic Review 110, 1-17.

Dhingra, S., H. Huang, G. Ottaviano, J. Paulo Pessoa, T. Sampson, and J. Van Reenen (2017, 10). The costs and benefits of leaving the EU: trade effects. Economic Policy 32(92), 651705 . 
Dixit, A. K. and R. S. Pindyck (1994). Investment Under Uncertainty. Princeton University Press.

Fernández-Villaverde, J., P. Guerrón-Quintana, K. Kuester, and J. Rubio-Ramírez (2015). Fiscal volatility shocks and economic activity. The American Economic Review 105(11), $3352-3384$.

Fetzer, T. (2019, November). Did austerity cause Brexit? The American Economic Review $109(11), 3849-86$.

Fisman, R. (2001). Estimating the value of political connections. The American Economic Review 91 (4), 1095-1102.

Fisman, R. and E. Zitzewitz (2019). An event long-short index: Theory and applications. American Economic Review: Insights 1(3), 357-72.

Forbes, K. J. and F. E. Warnock (2012). Capital flow waves: Surges, stops, flight, and retrenchment. Journal of International Economics 88(2), 235-251.

Garetto, S., L. Oldenski, and N. Ramondo (2019). Multinational expansion in time and space. Technical report, National Bureau of Economic Research.

Gentzkow, M., B. Kelly, and M. Taddy (2019). Text as data. Journal of Economic Literature 57(3), 535-74.

Gorbatikov, E., L. van Lent, N. Naik, V. Sharma, and A. Tahoun (2019). Is firm-specific political exposure priced? Working paper, London Business School.

Graziano, A., K. Handley, and N. Limão (2018). Brexit uncertainty and trade disintegration. Technical report, National Bureau of Economic Research.

Handley, K. and J. F. Li (2018). Measuring the effects of firm uncertainty on economic activity: New evidence from one million documents. Technical report, Mimeo., University of Michigan.

Hassan, T. A., S. Hollander, L. van Lent, and A. Tahoun (2019). Firm-level political risk: Measurement and effects. The Quarterly Journal of Economics 134(4), 2135-2202.

Hassan, T. A. and T. M. Mertens (2017). The social cost of near-rational investment. The American Economic Review 107(4), 1059-1103.

Hill, P., A. Korczak, and P. Korczak (2019). Political uncertainty exposure of individual companies: The case of the Brexit referendum. Journal of Banking EF Finance 100, 58-76.

Hollander, S., M. Pronk, and E. Roelofsen (2010). Does silence speak? an empirical analysis of disclosure choices during conference calls. Journal of Accounting Research 48(3), 531563.

Kost, K. (2019). Trade policy uncertainty, investment, and lobbying. Working paper, University of Chicago.

Loughran, T. and B. McDonald (2011). When is a liability not a liability? Textual analysis, dictionaries, and 10-Ks. The Journal of Finance 66(1), 35-65.

Loughran, T. and B. McDonald (2016). Textual analysis in accounting and finance: A survey. Journal of Accounting Research 54(14), 1187-1230. 
McGrattan, E. R. and A. Waddle (2017). The impact of Brexit on foreign investment and production. Working paper, National Bureau of Economic Research.

Pindyck, R. S. (1988). Irreversible investment, capacity choice, and the value of the firm. American Economic Review 78(5), 969.

Redding, S. and A. J. Venables (2004). Economic geography and international inequality. Journal of International Economics 62(1), 53-82.

Rey, H. (2015). Dilemma not trilemma: the global financial cycle and monetary policy independence. Technical report, National Bureau of Economic Research.

Sampson, T. (2017). Brexit: the economics of international disintegration. Journal of Economic Perspectives 31(4), 163-84.

Shumsky, T. (2018, Nov). SEC calls for more detailed disclosure on Brexit impact. Wall Street Journal.

Steinberg, J. B. (2019). Brexit and the macroeconomic impact of trade policy uncertainty. Journal of International Economics 117, 175-195.

Van Reenen, J. (2016). Brexit's long-run effects on the UK economy. Brookings papers on economic activity, 367-383.

Vandenbussche, H., W. Connell Garcia, and W. Simons (2019). Global value chains, trade shocks and jobs: an application to Brexit.

Waterfield, B., O. Wright, and H. Zeffman (2019, Oct). Growing risk of no-deal in six days after Macron blocks Brexit extension. www.thetimes.co.uk. 
Table 1: Data Coverage

\begin{tabular}{|c|c|c|}
\hline & \multicolumn{2}{|c|}{ Number of Sample Firms } \\
\hline & $\begin{array}{l}\text { Headquarter } \\
\text { country }\end{array}$ & $\begin{array}{c}\text { with UK } \\
\text { subsidiaries }\end{array}$ \\
\hline \multicolumn{3}{|c|}{ Panel A: By country group } \\
\hline UK & 396 & NA \\
\hline EU non-UK & 971 & 432 \\
\hline US & 3,791 & 1,633 \\
\hline Rest of the world & 2,575 & 776 \\
\hline \multicolumn{3}{|l|}{ Panel B: By country } \\
\hline USA & 3,791 & 1,633 \\
\hline Canada & 546 & 155 \\
\hline UK & 396 & NA \\
\hline Australia & 321 & 105 \\
\hline India & 270 & 65 \\
\hline China & 181 & 24 \\
\hline Japan & 153 & 95 \\
\hline Germany & 150 & 79 \\
\hline Sweden & 147 & 40 \\
\hline Brazil & 139 & 17 \\
\hline France & 130 & 77 \\
\hline Switzerland & 98 & 51 \\
\hline Hong Kong & 77 & 28 \\
\hline Netherlands & 76 & 40 \\
\hline Italy & 75 & 35 \\
\hline South Africa & 74 & 36 \\
\hline Norway & 68 & 23 \\
\hline Mexico & 68 & 7 \\
\hline Bermuda & 63 & 40 \\
\hline Israel & 61 & 28 \\
\hline Spain & 61 & 29 \\
\hline Ireland & 53 & 32 \\
\hline Denmark & 50 & 24 \\
\hline Finland & 45 & 19 \\
\hline Singapore & 41 & 11 \\
\hline Russia & 41 & 2 \\
\hline New Zealand & 39 & 5 \\
\hline S. Korea & 34 & 14 \\
\hline Luxembourg & 34 & 12 \\
\hline Taiwan & 33 & 11 \\
\hline Belgium & 31 & 9 \\
\hline Austria & 31 & 15 \\
\hline Poland & 28 & 6 \\
\hline Chile & 25 & 3 \\
\hline Turkey & 23 & 7 \\
\hline Thailand & 21 & 5 \\
\hline Greece & 20 & 1 \\
\hline Malaysia & 18 & 5 \\
\hline Argentina & 17 & 0 \\
\hline Philippines & 15 & 4 \\
\hline Colombia & 15 & 2 \\
\hline Indonesia & 15 & 1 \\
\hline UK Channel Islands & 15 & 6 \\
\hline Cyprus & 14 & 4 \\
\hline United Arab Emirates & 14 & 5 \\
\hline Nigeria & 12 & 5 \\
\hline Cayman Islands & 11 & 3 \\
\hline Peru & 10 & 0 \\
\hline Monaco & 10 & 1 \\
\hline Portugal & 9 & 4 \\
\hline Czech Republic & 6 & 2 \\
\hline Puerto Rico & 5 & 0 \\
\hline
\end{tabular}

Notes: This table reports the number of firms in our sample that are headquartered in each country (left column) and the number of these with one or more subsidiaries in the UK (right column). Panel A splits the sample by country group; Panel B splits by country. Countries with fewer than five headquartered firms are excluded. 
Table 2: Validation of BrexitExposure

\begin{tabular}{|c|c|c|c|c|}
\hline & \multicolumn{4}{|c|}{${\overline{\text { BrexitExposure }_{i}}}_{i}$} \\
\hline & (1) & (2) & (3) & (4) \\
\hline $\mathbb{1}\{\mathrm{UK} \mathrm{HQ}\}_{i}$ & $\begin{array}{c}0.872^{* * *} \\
(0.075)\end{array}$ & $\begin{array}{c}0.909 * * * \\
(0.075)\end{array}$ & $\begin{array}{c}0.064 \\
(0.088)\end{array}$ & $\begin{array}{c}0.116 \\
(0.092)\end{array}$ \\
\hline $\mathbb{1}\{\text { UK subsidiary }\}_{i}$ & $\begin{array}{c}0.188^{* * *} \\
(0.017)\end{array}$ & $\begin{array}{c}0.200^{* * *} \\
(0.017)\end{array}$ & $\begin{array}{c}0.227^{* * *} \\
(0.022)\end{array}$ & $\begin{array}{c}0.227^{* * *} \\
(0.021)\end{array}$ \\
\hline $\mathbb{1}\{\text { EU non-UK HQ }\}_{i}$ & & $\begin{array}{c}0.263^{* * *} \\
(0.032)\end{array}$ & $\begin{array}{c}0.073 \\
(0.087)\end{array}$ & $\begin{array}{c}0.072 \\
(0.084)\end{array}$ \\
\hline \% of sales in UK (2010-2015) & & & $\begin{array}{c}1.842^{* * *} \\
(0.405)\end{array}$ & \\
\hline$\%$ of sales in UK (2016-present) & & & & $\begin{array}{c}1.766^{* * * *} \\
(0.403) \\
\end{array}$ \\
\hline$R^{2}$ & 0.086 & 0.103 & 0.120 & 0.121 \\
\hline $\mathrm{N}$ & 7,733 & 7,733 & 3,497 & 3,678 \\
\hline
\end{tabular}

Notes: This table reports OLS estimates from cross-sectional regressions that use $\overline{\text { BrexitExposure }}_{i}$ as the dependent variable. We use 85,468 earnings calls between 2015Q1 and 2019Q1 to calculate firm-level mean Brexit exposure. Robust standard errors are in parenthesis. *, **, and *** indicate statistical significance at the 10, 5, and 1 percent levels, respectively. 
Figure 1: Time Series of BrexitRisk and BrexitSentiment

\section{Panel A: Brexit risk}

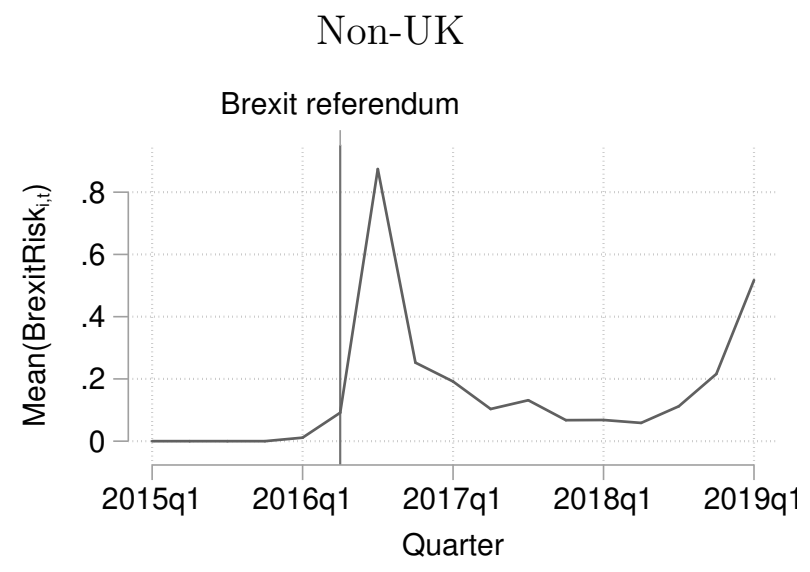

Panel B: Brexit sentiment

Non-UK

Brexit referendum

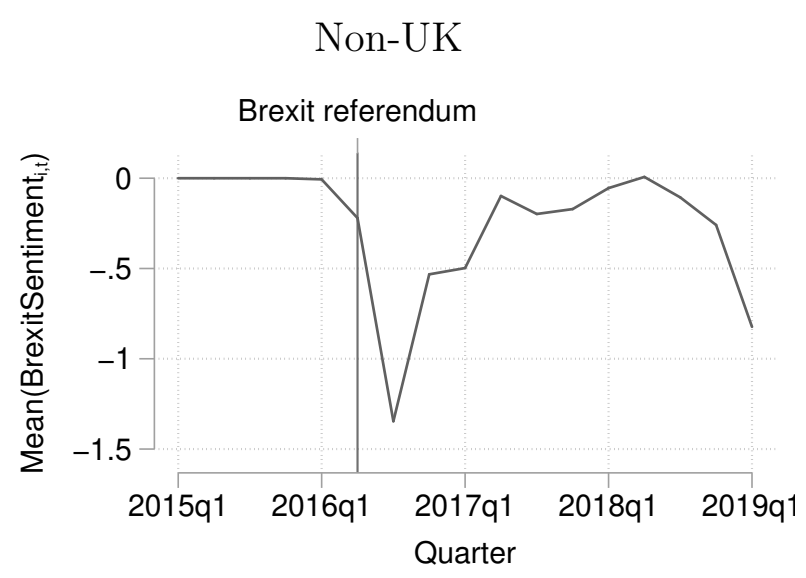

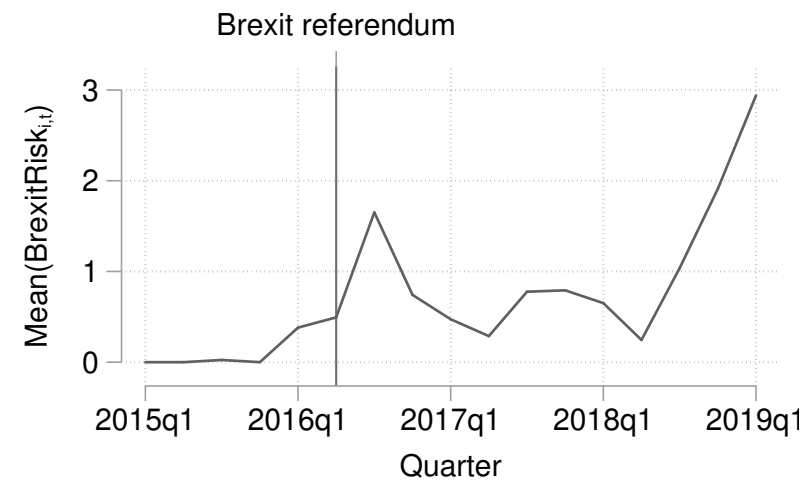

UK

Brexit referendum

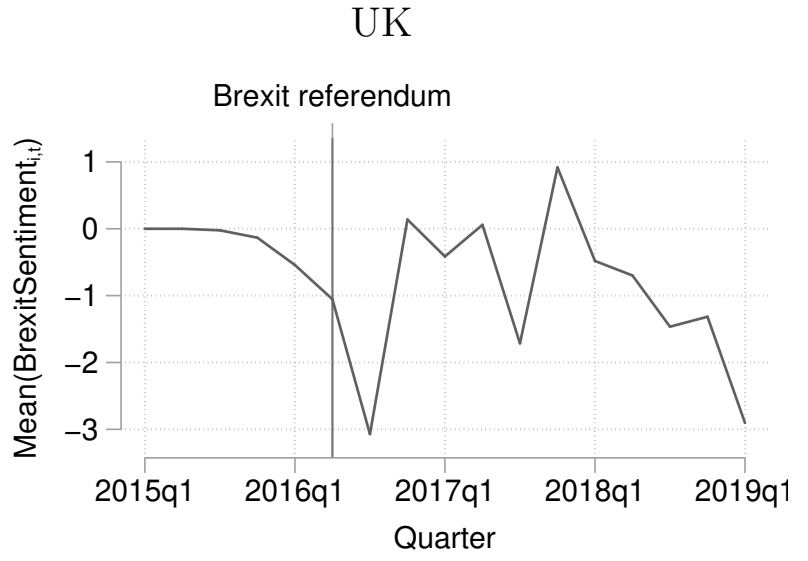

Notes: This figure plots the quarterly mean of non-UK and UK headquartered firms' Brexit risk (Panel A) and Brexit sentiment (Panel B). $\overline{\text { BrexitRisk }}_{i}$ is normalized using the average $\overline{\text { BrexitRisk }}_{i}$ of UK-headquartered firms; $\overline{\text { BrexitSentiment }}_{i}$ is normalized using the average $\left|\overline{\text { BrexitSentiment }}_{i}\right|$ of UK-headquartered firms. The Brexit referendum line indicates the quarter when the referendum took place (2016q2). 
Figure 2: Mean BrexitRisk by Country

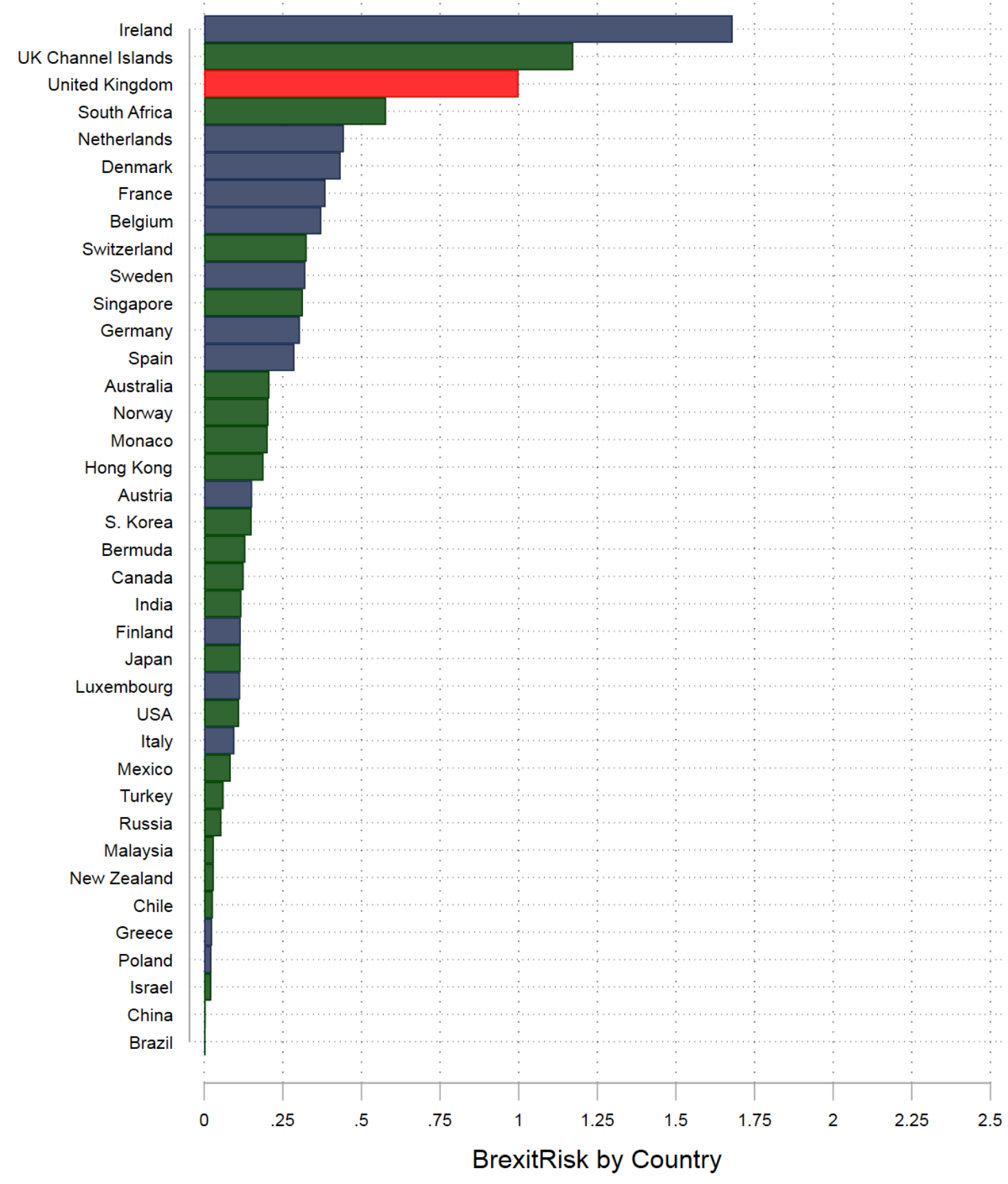

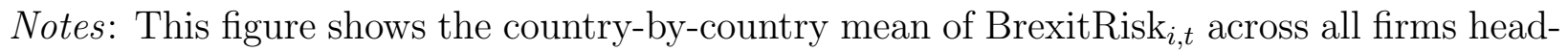
quartered in a specific country. Countries with zero $\overline{\text { BrexitRisk }}_{c}$ or countries for which we have fewer than five headquartered firms are excluded. Zero BrexitRisk countries include Puerto Rico, Thailand, Cayman Islands, Portugal, Indonesia, Cyprus, Nigeria, Czech Republic, United Arab Emirates, Argentina, Peru, Phillipines, and Columbia. 
Figure 3: BrexitRisk by Industry

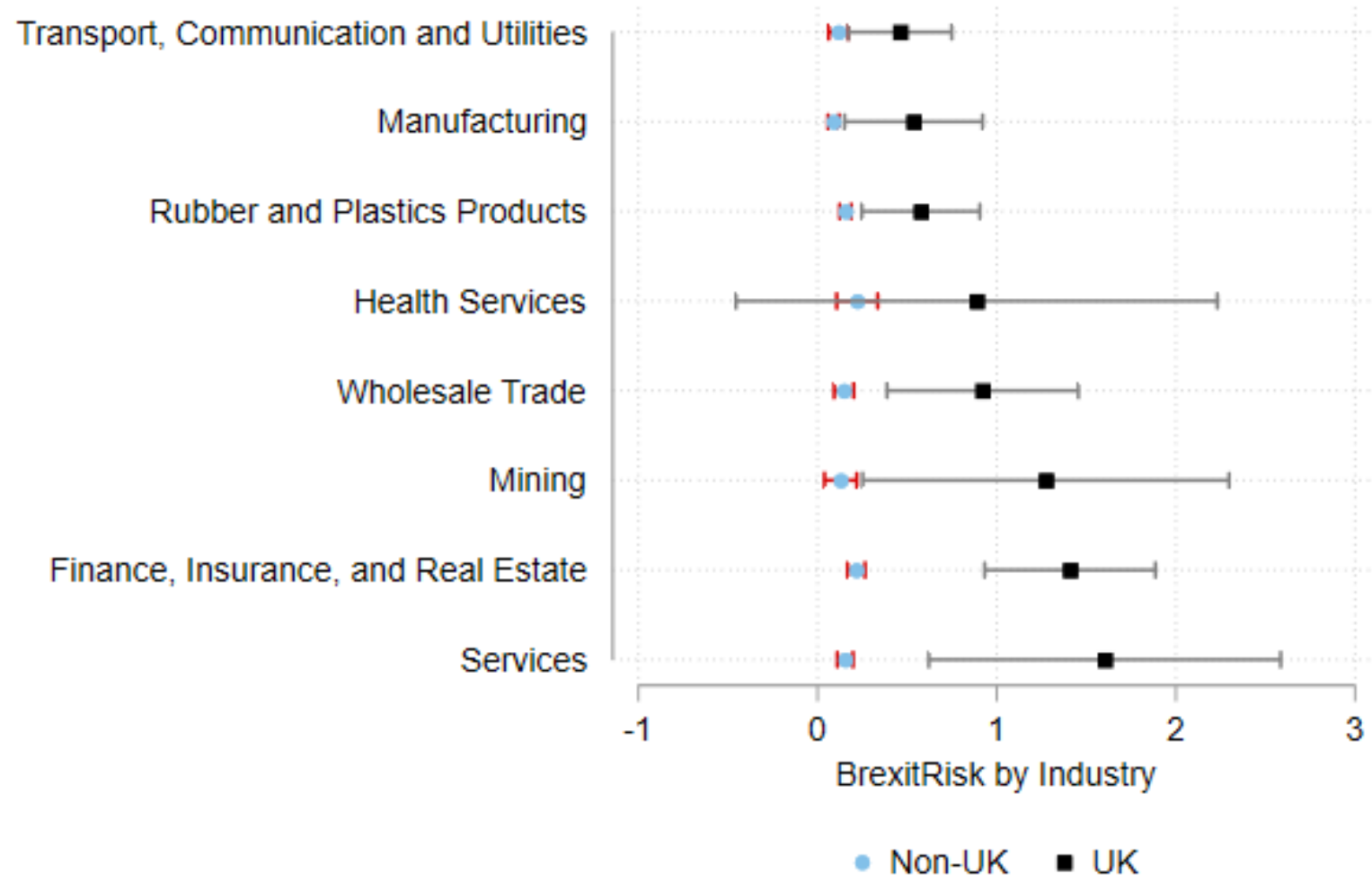

Notes: This figure shows the mean BrexitRisk ${ }_{i, t}$ by one-digit SIC industry for UK and nonUK firms. The confidence intervals around the industry means for BrexitRisk are calculated as $\left\{\overline{\text { BrexitRisk }}_{s}-t_{N-1} \frac{\sigma}{\sqrt{N}}, \overline{\text { BrexitRisk }}_{s}+t_{N-1} \frac{\sigma}{\sqrt{N}}\right\}$, where $\sigma$ is the standard deviation, $\mathrm{N}$ is the number of firms in the industry group, and $t_{N-1}$ is t-statistic with $N-1$ degrees of freedom. 


\section{Table 3: Top BrexitRisk Firms' Transcript Excerpts}

\begin{tabular}{|c|c|c|c|c|}
\hline \multicolumn{5}{|c|}{ Panel A: UK firms } \\
\hline Company & ${\overline{\text { BrexitRisk }_{i}}}_{1}$ & Country & Quarter & Transcript excerpts \\
\hline Bellway PLC & 18.89 & GB & 2018 Q4 & $\begin{array}{l}\text { deliver completions in fy we are mindful of the uncertainty sur- } \\
\text { rounding brexit and we will wait to see whether customer senti- } \\
\text { ment is affected }\end{array}$ \\
\hline Berendsen Ltd & 14.14 & GB & 2016 Q3 & $\begin{array}{l}\text { and we have i think a pretty proven resilient business however } \\
\text { brexit raises any number of uncertainties for every single busi- } \\
\text { ness so were }\end{array}$ \\
\hline SThree PLC & 13.64 & GB & 2019 Q1 & $\begin{array}{l}\text { year theres also a lot of uncertainty around the uk and brexit } \\
\text { and that will affect most markets but } i \text { think again the }\end{array}$ \\
\hline Endava PLC & 12.9 & GB & 2019 Q1 & $\begin{array}{l}\text { plans with us as a result of the uncertainties caused by brexit } \\
\text { mark will talk about how weve mitigated fx risk in his }\end{array}$ \\
\hline $\begin{array}{l}\text { Millennium \& } \\
\text { Copthorne Hotels } \\
\text { PLC }\end{array}$ & 10.48 & GB & 2018 Q1 & $\begin{array}{l}\text { as you know there is still uncertainty about british economy and } \\
\text { brexit for example we are seeing a rise in costs here because }\end{array}$ \\
\hline \multicolumn{5}{|c|}{ Panel B: Non-UK firms } \\
\hline Company & $\overline{\text { BrexitRisk }}_{i}$ & Country & Quarter & Transcript excerpts \\
\hline $\begin{array}{l}\text { Northstar Realty } \\
\text { Europe Corp }\end{array}$ & 18.35 & US & 2016 Q3 & $\begin{array}{l}\text { give rise to greater uncertainty this uncertainty has been exas- } \\
\text { perated by brexit the prospect of brexit has resulted in a high } \\
\text { degree of }\end{array}$ \\
\hline $\begin{array}{l}\text { Ryanair Holdings } \\
\text { PLC }\end{array}$ & 18.29 & IE & 2017 Q1 & $\begin{array}{l}\text { airlines the pricing environment has also been affected by the post } \\
\text { brexit uncertainty which has seen weaker sterling and a switch } \\
\text { of charter }\end{array}$ \\
\hline Breedon Group PLC & 17.58 & $\mathrm{JE}$ & 2019 Q1 & $\begin{array}{l}\text { quarter and the increased input costs but also an element of brexit } \\
\text { uncertainty in ireland our performance was strong and benefited } \\
\text { from the }\end{array}$ \\
\hline Sweco AB & 12.58 & $\mathrm{SE}$ & 2018 Q4 & $\begin{array}{l}\text { but still there is still an uncertainty when it comes to brexit and } \\
\text { some weakness in the real estate market so once again }\end{array}$ \\
\hline $\begin{array}{l}\text { Stonegate Mortgage } \\
\text { Corp }\end{array}$ & 11.65 & US & 2016 Q3 & $\begin{array}{l}\text { markets primarily driven by economic concerns abroad in particular } \\
\text { uncertainty around brexit played a major role related to the } \\
\text { instability of interest rates }\end{array}$ \\
\hline FBD Holdings PLC & 10.76 & IE & 2019 Q1 & $\begin{array}{l}\text { our agri and agribusiness customers are very exposed to a hard } \\
\text { brexit and any contingency planning that we can do and we have }\end{array}$ \\
\hline Nanosonics Ltd & 9.9 & $\mathrm{AU}$ & 2019 Q1 & $\begin{array}{l}\text { this in the uk but there is some underlying uncertainty around } \\
\text { brexit with the likes of confirmation of product supply chain ques- } \\
\text { tionnaires that }\end{array}$ \\
\hline $\begin{array}{l}\text { Bank of Ireland } \\
\text { Group PLC }\end{array}$ & 9.18 & IE & 2019 Q1 & $\begin{array}{l}\text { of the sme market continues to be impacted by the ongoing brexit } \\
\text { uncertainties our corporate banking business which includes } \\
\text { property lending had a }\end{array}$ \\
\hline Cairn Homes PLC & 8.75 & IE & 2019 Q1 & $\begin{array}{l}\text { enjoys we are all faced with uncertainty with the uncertainty } \\
\text { which brexit brings from a cairn perspective our operations are } \\
\text { currently all focused }\end{array}$ \\
\hline EQT Holdings Ltd & 8.58 & $\mathrm{AU}$ & 2019 Q1 & $\begin{array}{l}\text { about brexit and whether the uncertainty being driven by the } \\
\text { ultimate brexit solution and the timing of that is causing an issue } \\
\text { for }\end{array}$ \\
\hline
\end{tabular}

Notes: This table shows transcript excerpts for the top five UK (Panel A) and the top ten non-UK (Panel B) firms ranked by $\overline{\text { BrexitRisk }}_{i} . \overline{\text { BrexitRisk }}_{i}$ is calculated as the mean across all of a firm's available transcripts of earnings calls held between 2016 to 2019. Synonyms of risk and mentions of "Brexit" are in boldface. 
Figure 4: Mean BrexitSentiment by Country

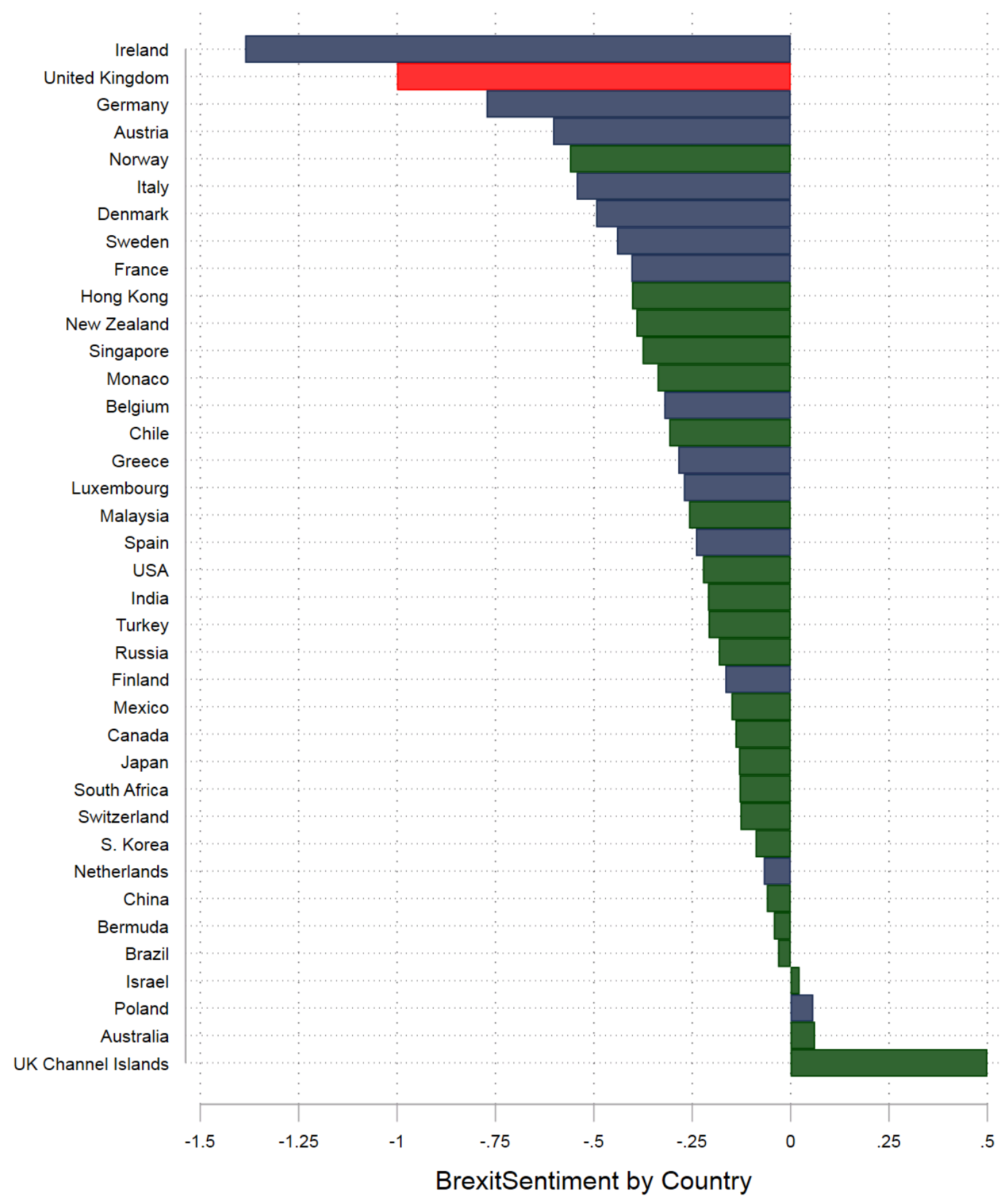

Notes: This figure shows the country-by-country mean of BrexitSentiment ${ }_{i, t}$ across all firms headquartered in a specific country. Countries with zero $\overline{\mathrm{BrexitRisk}}_{c}$ or countries for which we have fewer than five headquartered firms are excluded. Zero BrexitRisk countries include Puerto Rico, Thailand, Cayman Islands, Portugal, Indonesia, Cyprus, Nigeria, Czech Republic, United Arab Emirates, Argentina, Peru, Philippines, and Columbia. $\overline{\text { BrexitSentiment }}_{c}$ for the UK Channel Islands has a value of 2 but is truncated at 0.5 for visual clarity. 


\section{Table 4: Brexit-Related Concerns and Opportunities Expressed by Management}

\begin{tabular}{|c|c|c|c|}
\hline \multicolumn{4}{|c|}{ Panel A: Positive Brexit sentiment } \\
\hline Category & $\begin{array}{l}\text { UK } \\
\text { (in \%) }\end{array}$ & $\begin{array}{l}\text { Non-UK } \\
\text { (in \%) }\end{array}$ & Transcript excerpts \\
\hline Not exposed & 81.82 & 81.48 & $\begin{array}{l}\text { despite whats going on with the brexit noise so thus far we havent } \\
\text { seen a whole lot of softening and just to remind you our uk office } \\
\text { portfolio we have no financial institution exposure (Kennedy-Wilson } \\
\text { Holdings Inc, US, } 2019 \text { Q1) }\end{array}$ \\
\hline Weak pound & 18.18 & 17.59 & $\begin{array}{l}\text { saw a spike in leisure occupancy after the brexit referendum in june as } \\
\text { tourists took advantage of the cheaper pound (Millennium \& } \\
\text { Copthorne Hotels PLC, UK, } 2017 \text { Q1) }\end{array}$ \\
\hline $\begin{array}{l}\text { Relocation } \\
\text { opportunities }\end{array}$ & 4.55 & 2.78 & $\begin{array}{l}\text { potential opportunity coming from brexit and weve seen a number of } \\
\text { firms announcing that frankfurt would ultimately be their european } \\
\text { hub (Deutsche Boerse AG, DE, } 2017 \text { Q3) }\end{array}$ \\
\hline $\begin{array}{l}\text { Higher government } \\
\text { expenditure }\end{array}$ & 0 & 1.85 & $\begin{array}{l}\text { probably greater amount of private capital going into those assets } \\
\text { simply because of the other pressures on government spending so i } \\
\text { think brexit is neutral to who knows maybe mildly positive for us } \\
\text { (International Public Partnerships Ltd, GG, 2016 Q3) }\end{array}$ \\
\hline Better trade access & 0 & 1.85 & $\begin{array}{l}\text { brexit could be beneficial for forfarmers i can understand that it } \\
\text { might have a positive impact on your position in the uk (ForFarmers, } \\
\text { NL, } 2019 \text { Q1) }\end{array}$ \\
\hline Less regulation & 0 & 0 & NA \\
\hline
\end{tabular}

Panel B: Negative Brexit sentiment

\begin{tabular}{|c|c|c|c|}
\hline Category & $\begin{array}{l}\text { UK } \\
\text { (in \%) }\end{array}$ & $\begin{array}{l}\text { Non-UK } \\
\text { (in \%) }\end{array}$ & Transcript excerpts \\
\hline
\end{tabular}

Weak pound $\quad 47.06 \quad 60.69 \quad \begin{aligned} & \text { on the cost side weve had some cost headwinds fx particularly as } \\ & \text { sterling has still been weaker this year than last after brexit has } \\ & \text { impacted us (Flybe Group PLC, UK, 2018 Q2) }\end{aligned}$

\begin{tabular}{|c|c|c|c|}
\hline $\begin{array}{l}\text { Adjustment and } \\
\text { transition costs }\end{array}$ & 17.65 & 0.69 & $\begin{array}{l}\text { gbp million related to our investment in our operating platform } \\
\text { regulatory developments and brexit preparations (Jupiter Fund } \\
\text { Management PLC, UK, } 2019 \text { Q1) }\end{array}$ \\
\hline $\begin{array}{l}\text { New, multiple } \\
\text { regulatory regimes }\end{array}$ & 11.76 & 10.34 & $\begin{array}{l}\text { i sincerely hope that for the implementation of the brexit } \\
\text { reasonable solutions will be found that will preserve to a large } \\
\text { extent the rules of the single market for energy (Yunipro PAO, } \\
\text { RU, } 2016 \text { Q3) }\end{array}$ \\
\hline $\begin{array}{l}\text { Labor market } \\
\text { frictions }\end{array}$ & 11.76 & 8.97 & $\begin{array}{l}\text { labor market is getting tighter brexit will bring additional } \\
\text { challenges with regard to particularly experienced people within } \\
\text { all over banking organizations in ireland (Permanent TSB Group } \\
\text { Holdings PLC, IE, } 2018 \text { Q3) }\end{array}$ \\
\hline Worse trade access & 5.88 & 26.21 & $\begin{array}{l}\text { if the uk is unable to negotiate access to the single market or } \\
\text { open skies it may have implications for our three uk domestic } \\
\text { routes (Ryan Air Holdings, IE, 2016 Q3) }\end{array}$ \\
\hline $\begin{array}{l}\text { Falling consumer } \\
\text { confidence }\end{array}$ & 5.88 & 1.38 & $\begin{array}{l}\text { brexit has been and will continue to be a significant focus for } \\
\text { the industry over the coming months we will be affected by the } \\
\text { outcomes to the extent that there is significant changes in } \\
\text { consumer confidence (Auto Trader Group PLC, UK, } 2018 \text { Q4) }\end{array}$ \\
\hline
\end{tabular}

Notes: We manually classify positive (Panel A) and negative (Panel B) Brexit sentiment excerpts (+/- 10 words around a sentiment word) from earnings call transcripts into predefined categories. The numbers in the 'UK' and 'Non-UK' columns denote percentages from classified excerpts. They need not equal 100 because a transcript excerpt can be assigned to multiple categories. We classified excerpts from the top 100 positive and negative BrexitSentiment firms. We classified 128 out of 349 total positive sentiment excerpts, and 162 out of 549 total negative sentiment excerpts. Any remaining excerpts did not intersect with the predefined categories. Positive or negative tone words and mentions of "Brexit" are in boldface. 
Table 5: Summary Statistics

\begin{tabular}{|c|c|c|c|c|c|c|c|c|}
\hline & \multicolumn{3}{|c|}{ All firms } & \multicolumn{2}{|c|}{ UK firms } & \multicolumn{2}{|c|}{ Non-UK firms } & \multirow{2}{*}{$\frac{\text { Total }}{\mathrm{N}}$} \\
\hline & Mean & Median & $\mathrm{SD}$ & Mean & $\mathrm{SD}$ & Mean & $\mathrm{SD}$ & \\
\hline \multicolumn{9}{|c|}{ Panel A: Firm-level risk and sentiment } \\
\hline$\overline{\text { BrexitExposure }_{i}}$ & 0.211 & 0.000 & 0.674 & 1.000 & 1.496 & 0.169 & 0.568 & 7,733 \\
\hline$\overline{\text { BrexitRisk }_{i}}$ & 0.195 & 0.000 & 0.931 & 1.000 & 2.287 & 0.152 & 0.771 & 7,733 \\
\hline$\overline{\text { BrexitSentiment }_{i}}$ & -0.255 & 0.000 & 2.104 & -1.000 & 4.196 & -0.215 & 1.920 & 7,733 \\
\hline \multicolumn{9}{|l|}{ Panel B: Event study variables } \\
\hline Pre-BrexitExposure $_{i}$ & 0.037 & 0.000 & 0.304 & 0.281 & 0.782 & 0.029 & 0.274 & 3,907 \\
\hline Pre-BrexitRisk $_{i}$ & 0.032 & 0.000 & 0.441 & 0.173 & 1.199 & 0.028 & 0.395 & 3,907 \\
\hline Pre-BrexitSentiment ${ }_{i}$ & -0.048 & 0.000 & 1.087 & -0.131 & 2.121 & -0.045 & 1.040 & 3,907 \\
\hline Stock Returns $_{i}$ : June 24-28, 2016 & -0.034 & -0.030 & 0.066 & -0.096 & 0.096 & -0.032 & 0.064 & 4,691 \\
\hline \multicolumn{9}{|l|}{ Panel C: District level variables } \\
\hline Pct Votes for Leave ${ }_{c}$ & 48.816 & 50.769 & 11.334 & NA & NA & NA & NA & 116 \\
\hline Brexit Risk $_{c}$ & 1.000 & 0.375 & 1.585 & NA & NA & NA & NA & 116 \\
\hline Brexit Sentiment $_{c}$ & -1.000 & -0.065 & 4.442 & NA & NA & NA & NA & 116 \\
\hline \multicolumn{9}{|l|}{ Panel D: Firm-year outcomes } \\
\hline BrexitExposure $_{i, t}$ & 0.083 & 0.000 & 0.502 & 0.414 & 1.216 & 0.067 & 0.433 & 44,665 \\
\hline BrexitRisk $_{i, t}$ & 0.060 & 0.000 & 0.619 & 0.300 & 1.620 & 0.049 & 0.522 & 44,665 \\
\hline BrexitSentiment $_{i, t}$ & -0.088 & 0.000 & 1.822 & -0.351 & 4.215 & -0.075 & 1.618 & 44,665 \\
\hline Non-BrexitRisk $_{i, t}$ & 69.076 & 59.037 & 43.277 & 56.999 & 33.664 & 69.660 & 43.604 & 44,665 \\
\hline Non-BrexitSentiment $_{i, t}$ & 646.250 & 656.221 & 510.038 & 841.494 & 471.875 & 636.809 & 509.925 & 44,665 \\
\hline$I_{i, t+1} / K_{i, t} \cdot 100$ & 24.208 & 14.250 & 40.367 & 19.568 & 31.431 & 24.449 & 40.763 & 43,868 \\
\hline$\Delta e m p_{i, t} / e m p_{i, t-1} \cdot 100$ & 8.168 & 2.941 & 29.492 & 6.853 & 27.155 & 8.240 & 29.613 & 47,713 \\
\hline$\Delta$ sales $_{i, t} /$ sales $_{i, t-1} \cdot 100$ & 17.452 & 6.538 & 70.393 & 11.069 & 47.544 & 17.766 & 71.314 & 55,402 \\
\hline
\end{tabular}

Notes: This table shows the mean, median, standard deviation, and the number of firms for the variables used in the subsequent analysis. Columns 1 to 3 refers to the sample of all firms, Columns 4 and 5 to the sample of UK firms, and Columns 6 and 7 to the sample of non-UK firms. BrexitExposure, BrexitRisk, BrexitSentiment, Non-BrexitRisk and NonBrexitSentiment are calculated, as defined in section 2, for every call transcript by each firm in the sample. In Panel A, $\overline{\text { BrexitExposure }_{i}}, \overline{\text { BrexitRisk }_{i}}$, and $\overline{\text { BrexitSentiment }_{i}}$ are averages for each firm in the sample from 2016-2019, normalized by the mean $\overline{\text { BrexitRisk }_{i}}$, the mean $\overline{\text { BrexitRisk }_{i}}$ and absolute value of mean $\overline{\text { BrexitSentiment }_{i}}$ of firms in the UK, respectively. In Panel B, $\overline{\text { Pre-BrexitExposure }} i, \overline{\text { Pre-BrexitRisk }_{i}}$, and $\overline{\text { Pre-BrexitSentiment }_{i}}$ are calculated as in Panel A except with transcripts before June 23, 2016 (day of the Brexit Referendum). Stock returns $i_{i}$ are calculated as $\sum_{t=0}^{t=N} \log \left(P_{i, t} / P_{i, t-1}\right)$, where $\mathrm{t}$ is at a daily frequency, and $[0, N]$ represents the period of four trading days (including weekend days) following the Brexit referendum starting on June 24 and ending on June 29, 2016. In Panel C, Pct Votes for Leave ${ }_{d}$ is percentage votes for leave cast by a district in the UK, and $\overline{\text { BrexitRisk }_{i}}$ and $\overline{\text { BrexitSentiment }_{i}}$ are calculated by taking an average across firms headquartered in a district. $\overline{\text { BrexitRisk }_{i}}$ and $\overline{\text { BrexitSentiment }_{i}}$ are normalized such that the mean of $\overline{\text { BrexitRisk }_{i}}$ is 1 and $\overline{\text { BrexitSentiment }_{i}}$ is -1 across cross-section of districts. In Panel D, the sample period for yearly outcomes is 2011-2018; BrexitExposure ${ }_{i, t}$, BrexitRisk $_{i, t}$, BrexitSentiment ${ }_{i, t}$, Non-BrexitRisk ${ }_{i, t}$ and Non-BrexitSentiment ${ }_{i, t}$ are calculated as firm-year averages across all transcripts by a firm in a year. BrexitRisk ${ }_{i, t}$ and Non-BrexitRisk $i, t$ are normalized by the average BrexitRisk ${ }_{i, t}$ for UK firms post 2016. BrexitSentiment $t_{i, t}$ is normalized by the absolute average of BrexitSentiment ${ }_{i, t}$ for UK firms post 2016. 
Table 6: Event Study

\begin{tabular}{|c|c|c|c|c|c|}
\hline & \multicolumn{5}{|c|}{ Stock Returns: June 24-28, 2016} \\
\hline & (1) & $(2)$ & $(3)$ & $(4)$ & $(5)$ \\
\hline Panel A: & \multicolumn{5}{|c|}{ All firms } \\
\hline$\overline{\text { BrexitExposure }_{i}}$ & $\begin{array}{c}-0.026^{* * *} \\
(0.003)\end{array}$ & $\begin{array}{c}-0.026^{* * *} \\
(0.003)\end{array}$ & & & \\
\hline$\overline{\text { BrexitRisk }_{i}}$ & & & $\begin{array}{c}-0.011^{* * *} \\
(0.002)\end{array}$ & $\begin{array}{c}-0.011^{* * *} \\
(0.002)\end{array}$ & \\
\hline$\overline{\text { BrexitSentiment }_{i}}$ & & & $\begin{array}{c}0.002^{* *} \\
(0.001)\end{array}$ & $\begin{array}{c}0.002^{* *} \\
(0.001)\end{array}$ & \\
\hline Pre-BrexitRisk $_{i}$ & & & & & $\begin{array}{c}-0.006^{* * *} \\
(0.002)\end{array}$ \\
\hline Pre-BrexitSentiment $_{i}$ & & & & & $\begin{array}{c}0.001 \\
(0.001)\end{array}$ \\
\hline Constant & $\begin{array}{c}-0.008^{*} \\
(0.004) \\
\end{array}$ & $\begin{array}{c}0.003 \\
(0.005) \\
\end{array}$ & $\begin{array}{l}-0.007 \\
(0.005) \\
\end{array}$ & $\begin{array}{c}0.005 \\
(0.005) \\
\end{array}$ & $\begin{array}{c}0.005 \\
(0.006) \\
\end{array}$ \\
\hline$R^{2}$ & 0.156 & 0.192 & 0.140 & 0.175 & 0.170 \\
\hline $\mathrm{N}$ & 3,875 & 3,834 & 3,875 & 3,834 & 3,422 \\
\hline PANEL B: & \multicolumn{5}{|c|}{ US firms } \\
\hline$\overline{\text { BrexitExposure }_{i}}$ & $\begin{array}{c}-0.024^{* * *} \\
(0.003)\end{array}$ & $\begin{array}{c}-0.023^{* * *} \\
(0.002)\end{array}$ & & & \\
\hline$\overline{\text { BrexitRisk }_{i}}$ & & & $\begin{array}{c}-0.008^{* * *} \\
(0.001)\end{array}$ & $\begin{array}{c}-0.007^{* * *} \\
(0.002)\end{array}$ & \\
\hline$\overline{\text { BrexitSentiment }_{i}}$ & & & $\begin{array}{c}0.004^{* * *} \\
(0.001)\end{array}$ & $\begin{array}{c}0.004^{* * *} \\
(0.001)\end{array}$ & \\
\hline Pre-BrexitRisk $_{i}$ & & & & & $\begin{array}{c}-0.005^{* *} \\
(0.002)\end{array}$ \\
\hline Pre-BrexitSentiment ${ }_{i}$ & & & & & $\begin{array}{c}0.002^{* *} \\
(0.001)\end{array}$ \\
\hline Constant & $\begin{array}{c}-0.009 * \\
(0.005) \\
\end{array}$ & $\begin{array}{c}0.009 \\
(0.006)\end{array}$ & $\begin{array}{l}-0.007 \\
(0.005) \\
\end{array}$ & $\begin{array}{l}0.010^{*} \\
(0.006) \\
\end{array}$ & $\begin{array}{l}0.010 * \\
(0.006)\end{array}$ \\
\hline$R^{2}$ & 0.067 & 0.124 & 0.059 & 0.116 & 0.118 \\
\hline $\mathrm{N}$ & 2,806 & 2,777 & 2,806 & 2,777 & 2,531 \\
\hline Beta controls & $\mathrm{N}$ & $\mathrm{Y}$ & $\mathrm{N}$ & $\mathrm{Y}$ & $\mathrm{Y}$ \\
\hline
\end{tabular}

Notes: This table reports OLS estimation results from cross-sectional regressions of stock returns from June 24 to June 28, 2016 on $\overline{\text { BrexitRisk }_{i}}$ and $\overline{\text { BrexitSentiment }_{i}}$, separately for all firms (Panel A) and for US headquartered firms (Panel B). Stock returns are calculated as $\sum_{t=0}^{t=N} \log \left(P_{i, t} / P_{i, t-1}\right)$, where $\mathrm{t}$ is at a daily frequency, and $[0, \mathrm{~N}]$ represents the period of four trading days (including weekend days) following the Brexit referendum starting on June 24 and ending on June 29, 2016. All other variables are as defined in table 5. All specifications include one-digit-SIC and headquarters-country fixed effects (with the exception of Panel B). Standard errors are clustered by firm. *, **, and *** indicate statistical significance at the 10,5 , and 1 percent levels, respectively. These regressions exclude non-UK firms with less than seven transcripts in the sample, and firms in the 'Non Classifiable' sector. 
Figure 5: Alternative Event Windows around the Referendum

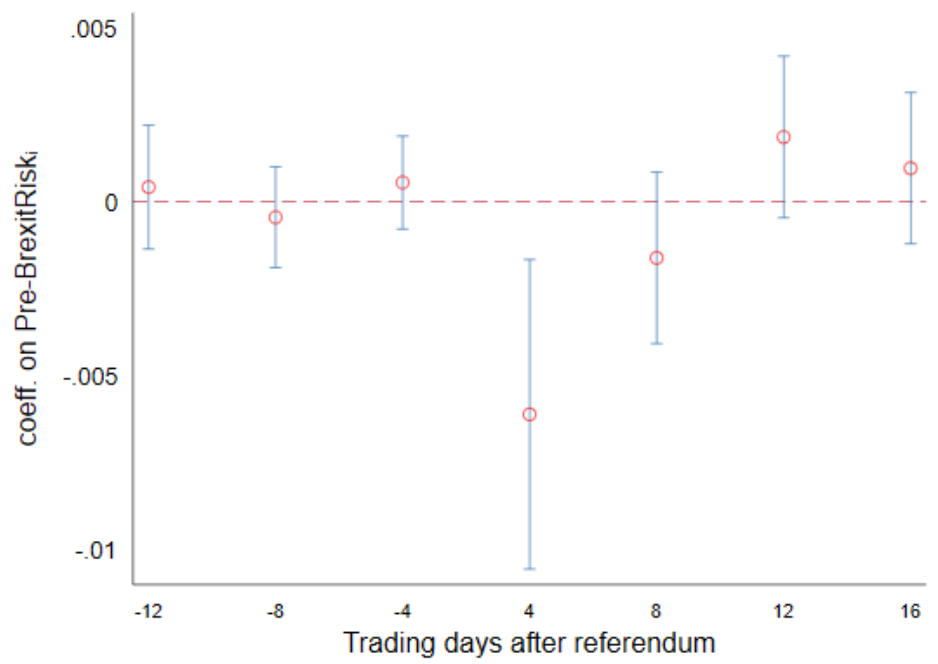

Notes: This figure shows coefficients and $95 \%$ confidence intervals of Pre-BrexitRisk for $_{i}$ three consecutive event windows before and after the June 23, 2016 Brexit referendum using the specification in Column 5 of Table 6. Each event window consists of 4 consecutive trading days.

Figure 6: Effect of Brexit Risk on Stock Returns: June 24-28, 2016
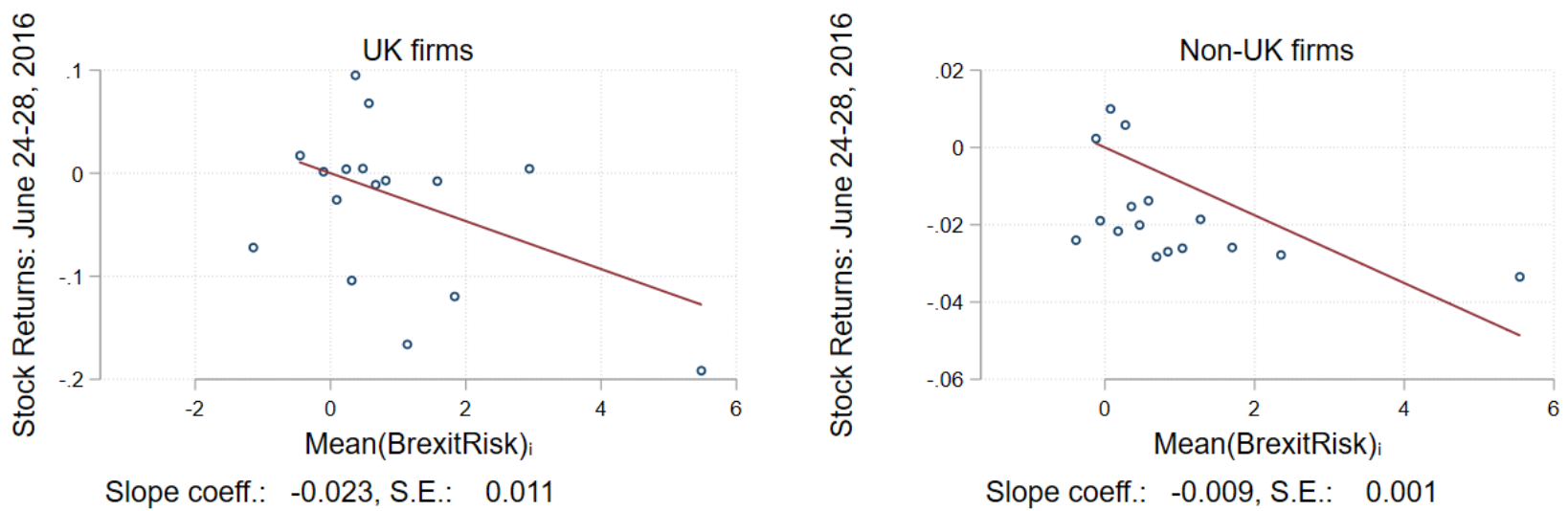

Notes: These figures show binned scatter plots and a linear regression line for the relationship between stock returns from June 24 to June 28,2016 and $\overline{\text { BrexitRisk }_{i}}$ for firms headquartered in the UK (left panel) and outside of the UK (right panel). The relationship is plotted after controlling for $\overline{\text { BrexitSentiment }_{i}}, \log$ (assets), and one-digit-SIC and country fixed effects. Standard errors are clustered by firm. Each scatter plot has 16 bins: the first bin has all firm-year observations with zero $\overline{\text { BrexitRisk }_{i}}$; the other 15 bins are equally populated with non-zero firm-year observations $\overline{\text { BrexitRisk }_{i}}$. 
Table 7: Voting in Brexit Referendum

\begin{tabular}{lccc}
\hline & \multicolumn{3}{c}{ Pct. Vote for Leave } \\
\cline { 2 - 4 } & $(1)$ & $(2)$ & $(3)$ \\
\hline BrexitRisk $_{d}$ & $\begin{array}{c}-0.838^{*} \\
(0.456)\end{array}$ & $\begin{array}{c}-0.929^{* *} \\
\text { (0.378) }\end{array}$ \\
BrexitSentiment $_{d}$ & & $\begin{array}{c}0.358^{* * *} \\
(0.133)\end{array}$ & $\begin{array}{c}0.386^{* * *} \\
(0.114)\end{array}$ \\
Share UK born $_{d}$ & $50.481^{* * *}$ & $51.592^{* * *}$ & $52.395^{* * *}$ \\
& $(7.296)$ & $(7.484)$ & $(7.380)$ \\
Income per capita $_{d}$ & $-0.024^{* * *}$ & $-0.022^{* * *}$ & $-0.023^{* * *}$ \\
& $(0.004)$ & $(0.003)$ & $(0.004)$ \\
\hline$R^{2}$ & 0.580 & 0.586 & 0.604 \\
$\mathrm{~N}$ & 110 & 110 & 110 \\
\hline
\end{tabular}

Notes: This table reports OLS estimates from crosssectional regressions of Pct Vote for Leave ${ }_{d}$ on BrexitRisk ${ }_{d}$ and BrexitSentiment ${ }_{d}$, as defined in table 5. Share UK $\operatorname{born}_{d}$ (the share of people born in the UK in a district $d)$, and Income per cepita $d$ are controls in the regression measured for district $d$ as reported in the 2011 census. We use 2,945 transcripts of the earnings calls of 407 unique sample firms held between 2015- Q1 and 2019-Q1 to calculate firm-level means. Standard errors are robust. *, **, and $* * *$ indicate statistical significance at the 10,5 , and 1 percent levels, respectively. 
Figure 7: Voting in Brexit Referendum: Column 3 of Table 7

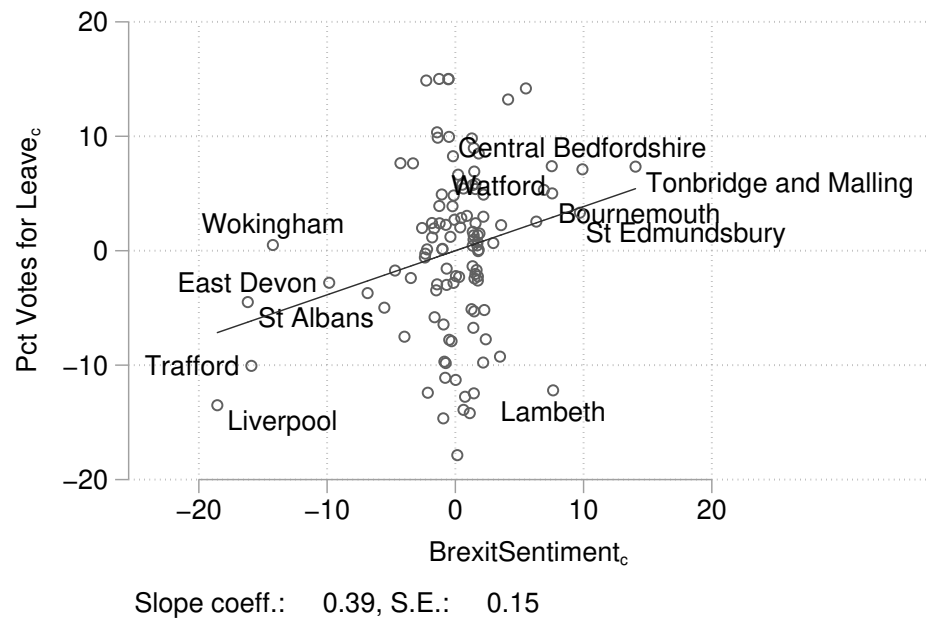

Notes: This figure presents an added variable plot for the specification in Column 3 of Table 7. We label the observations with a residual value larger than 1.6 standard deviations from the sample mean. 
Figure 8: BrexitRisk ${ }_{i, t}$ and Firm Investment

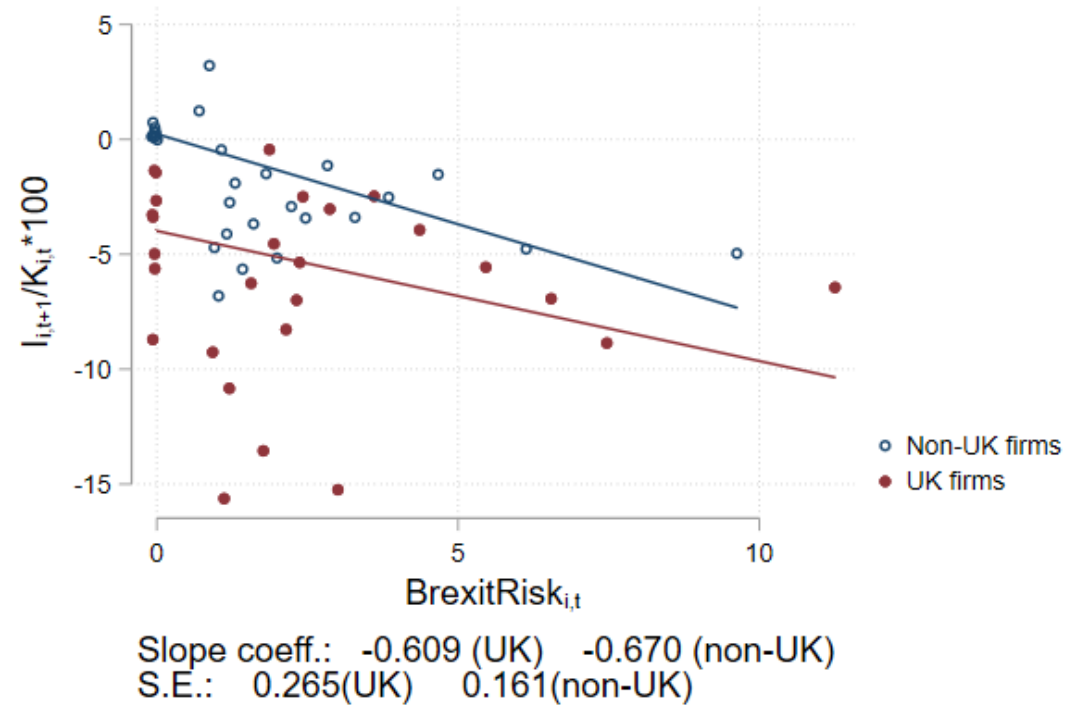

Notes: This figure shows the binned scatter plot and the linear regression line for the regression of $I_{i, t+1} / K_{i, t} \cdot 100$ on BrexitRisk ${ }_{i, t}$, separately for UK firms (red) and non-UK firms (blue) and controlling for $\log$ (assets), one-digit-SIC and year fixed effects. Standard errors are clustered by firm. The scatter plot has 29 bins for UK and non-UK firms: The first nine bins are for all firm-year observations with zero BrexitRisk ${ }_{i, t}$ grouped by nine one-digit SIC codes; the other 20 bins are equally populated by firm-year observations with non-zero BrexitRisk B $_{i, t}$. 
Table 8: BrexitRisk ${ }_{i, t}$, BrexitSentiment ${ }_{i, t}$ and Firm Investment

\begin{tabular}{|c|c|c|c|c|c|}
\hline & \multicolumn{5}{|c|}{$I_{i, t+1} / K_{i, t} \cdot 100$} \\
\hline & $(1)$ & $(2)$ & $(3)$ & (4) & $(5)$ \\
\hline PANEL A & \multicolumn{5}{|c|}{ All firms } \\
\hline BrexitRisk $_{i, t}$ & $\begin{array}{c}-0.843^{* * *} \\
(0.175)\end{array}$ & $\begin{array}{c}-0.788^{* * *} \\
(0.190)\end{array}$ & $\begin{array}{c}-0.663^{* * *} \\
(0.185)\end{array}$ & $\begin{array}{c}-0.628^{* * *} \\
(0.182)\end{array}$ & $\begin{array}{c}-0.640^{* * *} \\
(0.184)\end{array}$ \\
\hline BrexitSentiment $_{i, t}$ & $\begin{array}{l}-0.115 \\
(0.094)\end{array}$ & $\begin{array}{l}-0.117 \\
(0.093)\end{array}$ & $\begin{array}{l}-0.108 \\
(0.097)\end{array}$ & $\begin{array}{l}-0.107 \\
(0.096)\end{array}$ & $\begin{array}{l}-0.115 \\
(0.097)\end{array}$ \\
\hline BrexitRisk $_{i, t} \times \mathbb{1}\{\mathrm{UK}$ HQ $\}$ & & $\begin{array}{c}0.093 \\
(0.331)\end{array}$ & & & \\
\hline Non-BrexitRisk $_{i, t}$ & & & & $\begin{array}{c}-0.024^{* * *} \\
(0.006)\end{array}$ & $\begin{array}{c}-0.018^{* * *} \\
(0.006)\end{array}$ \\
\hline Non-BrexitSentiment $_{i, t}$ & & & & & $\begin{array}{c}0.002^{* * *} \\
(0.001)\end{array}$ \\
\hline$R^{2}$ & 0.034 & 0.035 & 0.068 & 0.069 & 0.070 \\
\hline $\mathrm{N}$ & 22,225 & 22,225 & 22,204 & 22,204 & 22,204 \\
\hline Year FE & $\mathrm{Y}$ & $\mathrm{Y}$ & $\mathrm{Y}$ & $\mathrm{Y}$ & $\mathrm{Y}$ \\
\hline Industry FE & $\mathrm{Y}$ & $\mathrm{Y}$ & $\mathrm{Y}$ & $\mathrm{Y}$ & $\mathrm{Y}$ \\
\hline Industry $\mathrm{x}$ year FE & $\mathrm{N}$ & $\mathrm{N}$ & Y & $\mathrm{Y}$ & $\mathrm{Y}$ \\
\hline Country FE & $\mathrm{N}$ & $\mathrm{N}$ & $\mathrm{Y}$ & $\mathrm{Y}$ & $\mathrm{Y}$ \\
\hline PANEL B & & & US firms & & \\
\hline BrexitRisk $_{i, t}$ & $\begin{array}{c}-1.089 * * * \\
(0.344) \\
\end{array}$ & $\begin{array}{c}-1.089^{* * *} \\
(0.344) \\
\end{array}$ & $\begin{array}{c}-1.079^{* * *} \\
(0.343) \\
\end{array}$ & $\begin{array}{c}-0.994^{* * *} \\
(0.342) \\
\end{array}$ & $\begin{array}{c}-1.026^{* * *} \\
(0.344) \\
\end{array}$ \\
\hline$R^{2}$ & 0.042 & 0.042 & 0.070 & 0.071 & 0.072 \\
\hline $\mathrm{N}$ & 14,219 & 14,219 & 14,198 & 14,198 & 14,198 \\
\hline Year FE & $\mathrm{Y}$ & $\mathrm{Y}$ & $\mathrm{Y}$ & $\mathrm{Y}$ & $\mathrm{Y}$ \\
\hline Industry FE & $\mathrm{Y}$ & Y & Y & $\mathrm{Y}$ & $\mathrm{Y}$ \\
\hline Industry x year FE & $\mathrm{N}$ & $\mathrm{N}$ & $\mathrm{Y}$ & $\mathrm{Y}$ & $\mathrm{Y}$ \\
\hline
\end{tabular}

Notes: This table reports results from regressions of $I_{i, t+1} / K_{i, t} \cdot 100$ on BrexitRisk B $_{i, t}$ and BrexitSentiment $_{i, t}$ using yearly data, separately for the full sample (Panel A) and for sample firms headquartered in the US (Panel B). BrexitRisk ${ }_{i, t}$ and BrexitSentiment ${ }_{i, t}$ are calculated by taking the yearly average across a firm's quarterly earnings call transcripts. The dependent variable is winsorized at the 1st and 99th percentile. The regressions include controls for $\log$ (assets) and for year, two-digit-SIC, and country (with the exception of the Panel B specifications) fixed effects. The regressions exclude non-UK firms with fewer than 10 transcripts in 2015-2018, and firms in the 'Non Classifiable' sector. Standard errors are clustered by firm. ${ }^{*},{ }^{*}$, and $* * *$ indicate statistical significance at the 10,5 , and 1 percent levels, respectively. 
Table 9: Placebo Tests: BrexitRisk ${ }_{i, t}$, BrexitSentiment ${ }_{i, t}$, and Firm Investment

\begin{tabular}{|c|c|c|c|c|c|c|}
\hline & \multicolumn{6}{|c|}{$I_{i, t+1} / K_{i, t} \cdot 100$} \\
\hline & $(1)$ & $(2)$ & $(3)$ & (4) & $(5)$ & (6) \\
\hline BrexitRisk $_{i, t}$ & $\begin{array}{c}-0.640^{* * *} \\
(0.184)\end{array}$ & $\begin{array}{c}-0.836^{* * *} \\
(0.283)\end{array}$ & $\begin{array}{c}-0.513^{* * *} \\
(0.180)\end{array}$ & $\begin{array}{c}-0.692^{* * *} \\
(0.186)\end{array}$ & $\begin{array}{c}-0.686^{* * *} \\
(0.206)\end{array}$ & $\begin{array}{c}-0.699 * * * \\
(0.218)\end{array}$ \\
\hline Earnings surprise $_{i, t}$ & & $\begin{array}{l}-0.037 \\
(0.044)\end{array}$ & & & & \\
\hline Stock return $_{i, t}$ & & & $\begin{array}{c}0.254^{* * *} \\
(0.028)\end{array}$ & & & \\
\hline PRiskTrade $_{i, t}$ (std.) & & & & $\begin{array}{c}-0.402^{*} \\
(0.209)\end{array}$ & & \\
\hline Average UK sales ${ }_{i}$ (pre-Brexit) & & & & & $\begin{array}{c}1.476 \\
(4.301)\end{array}$ & \\
\hline$\overline{\text { BrexitExposure }_{i}}$ & & & & & & $\begin{array}{c}0.463 \\
(1.007)\end{array}$ \\
\hline$R^{2}$ & 0.070 & 0.081 & 0.084 & 0.075 & 0.097 & 0.070 \\
\hline $\mathrm{N}$ & 22,204 & 15,728 & 21,176 & 21,156 & 15,301 & 22,204 \\
\hline Controls & Y & $\mathrm{Y}$ & $\mathrm{Y}$ & $\mathrm{Y}$ & $\mathrm{Y}$ & Y \\
\hline Year FE & Y & $\mathrm{Y}$ & Y & $\mathrm{Y}$ & $\mathrm{Y}$ & Y \\
\hline Industry FE & $\mathrm{Y}$ & $\mathrm{Y}$ & $\mathrm{Y}$ & Y & $\mathrm{Y}$ & $\mathrm{Y}$ \\
\hline Industry x Year FE & Y & $\mathrm{Y}$ & Y & Y & $\mathrm{Y}$ & $\mathrm{Y}$ \\
\hline Country FE & $\mathrm{Y}$ & $\mathrm{Y}$ & Y & Y & $\mathrm{Y}$ & $\mathrm{Y}$ \\
\hline
\end{tabular}

Notes: This table reports estimation results from regressions of $I_{i, t+1} / K_{i, t} \cdot 100$ on BrexitRisk B $_{i, t}$ and BrexitSentiment $_{i, t}$ using yearly data for the full sample. BrexitRisk $k_{i, t}$ is defined as in Table 8. Earnings surprise $e_{i, t}$ is defined as $\left(\mathrm{EPS}_{i, t}\right.$-EPS $\left._{i, t-1}\right) /$ end-of-year stock price ${ }_{i, t}$, where $\mathrm{EPS}_{i, t}$ are earnings per share of firm $i$ during year $t$ (Compustat item epspx). Stock return $n_{i, t}$ is the annual average of quarter-on-quarter stock return. PRiskTrade ${ }_{i, t}$ (std.) is the Political Risk: Trade Policy Index from Hassan et al. (2019), standardized by its own standard deviation. All specifications control for log(assets) and for year, twodigit-SIC, and country fixed effects. The dependent variable is winsorized at the 1st and 99th percentile. The regressions exclude non-UK firms with fewer than 10 transcripts in 2015-2018, and firms in the 'Non Classifiable' sector. Standard errors are clustered by firm. ${ }^{*}, * *$, and $* * *$ indicate statistical significance at the 10,5 , and 1 percent levels, respectively. 
Figure 9: Placebo Test: Counterfactual Brexit

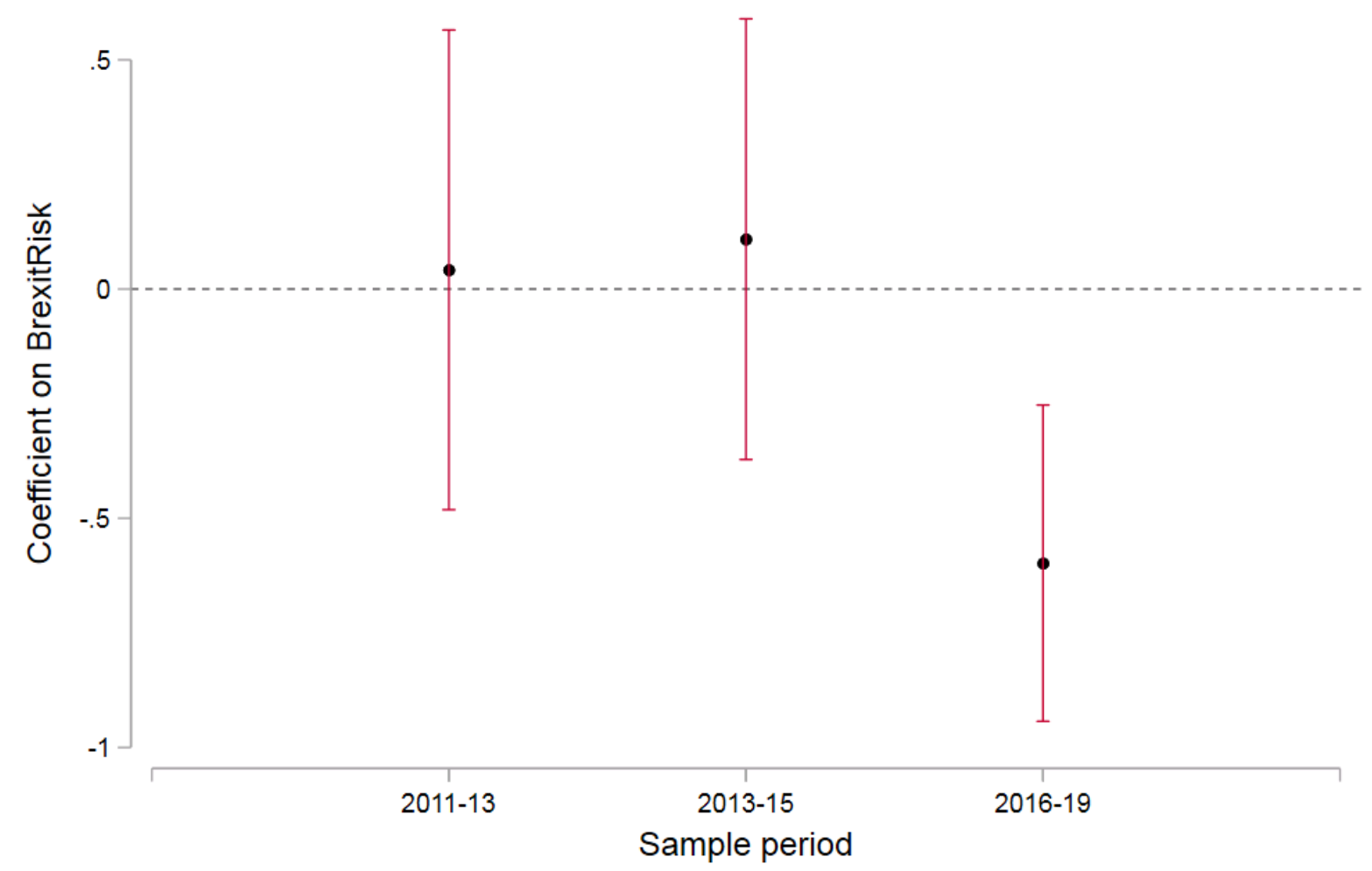

Notes: This figure plots coefficient estimates and $95 \%$ confidence intervals for BrexitRisk $_{i, t}$ from three separate panel regressions of $I_{i, t+1} / K_{i, t} \cdot 100$ on BrexitRisk B $_{i, t}$ and the same control variables as in Column 5 of Table 8. For the 2011-13 and 2013-15 sample periods, we have reassigned each firm's time series of 20162018 BrexitRisk $_{i, t}$ to the sample period indicated; for the 2016-19 sample period, BrexitRisk $_{i, t}$ is the firm's actual BrexitRisk ${ }_{i, t}$ in that sample period. 
Table 10: BrexitRisk ${ }_{i, t}$, BrexitSentiment $t_{i, t}$, and Other Firm Outcomes

\begin{tabular}{|c|c|c|c|c|}
\hline \multirow{3}{*}{$\begin{array}{l}\text { PANel A } \\
\text { BrexitRisk }_{i, t}\end{array}$} & \multicolumn{4}{|c|}{$\Delta e m p_{i, t} / e m p_{i, t-1} \cdot 100$} \\
\hline & \multicolumn{2}{|c|}{ All firms } & \multicolumn{2}{|c|}{ US firms } \\
\hline & $-0.495^{* * *}$ & $-0.391^{* *}$ & $-1.211^{* * *}$ & $-1.272^{* * *}$ \\
\hline & (0.179) & $(0.179)$ & $(0.430)$ & $(0.460)$ \\
\hline \multirow[t]{2}{*}{ BrexitSentiment $_{i, t}$} & -0.016 & -0.011 & -0.219 & -0.197 \\
\hline & $(0.084)$ & $(0.082)$ & $(0.201)$ & $(0.207)$ \\
\hline$R^{2}$ & 0.024 & 0.052 & 0.027 & 0.057 \\
\hline $\mathrm{N}$ & 27,156 & 27,141 & 18,117 & 18,099 \\
\hline \multirow[t]{2}{*}{ Panel B } & \multicolumn{4}{|c|}{$\Delta$ sales $_{i, t} /$ sales $_{i, t-1} \cdot 100$} \\
\hline & \multicolumn{2}{|c|}{ All firms } & \multicolumn{2}{|c|}{ US firms } \\
\hline \multirow[t]{2}{*}{ BrexitRisk $_{i, t}$} & -0.396 & -0.135 & -0.091 & -0.096 \\
\hline & $(0.253)$ & $(0.251)$ & $(0.613)$ & $(0.591)$ \\
\hline \multirow[t]{2}{*}{ BrexitSentiment $_{i, t}$} & 0.118 & $0.135^{*}$ & $0.305^{* *}$ & $0.410^{* *}$ \\
\hline & $(0.075)$ & $(0.081)$ & $(0.142)$ & $(0.167)$ \\
\hline$R^{2}$ & 0.025 & 0.052 & 0.035 & 0.058 \\
\hline $\mathrm{N}$ & 29,059 & 29,042 & 18,846 & 18,828 \\
\hline Controls & Y & Y & Y & Y \\
\hline Year FE & Y & Y & Y & Y \\
\hline Industry FE & Y & Y & Y & Y \\
\hline Industry $\times$ Year FE & $\mathrm{N}$ & Y & $\mathrm{N}$ & $\mathrm{Y}$ \\
\hline Country FE & $\mathrm{N}$ & Y & $\mathrm{n} / \mathrm{a}$ & $\mathrm{n} / \mathrm{a}$ \\
\hline
\end{tabular}

Notes: This table reports results from panel regressions of $\Delta e m p_{i, t} /$ emp $_{i, t-1} \cdot 100$ (Panel A) and $\Delta$ sales $_{i, t} /$ sales $_{i, t-1} \cdot 100$ (Panel B) on BrexitRisk ${ }_{i, t}$ and BrexitSentiment ${ }_{i, t}$. BrexitRisk ${ }_{i, t}$ and BrexitSentiment $_{i, t}$ are calculated as in Table 8. All specifications control for Non-BrexitRisk ${ }_{i, t}$, Non-BrexitSentiment $t_{i, t}$, and $\log$ (assets) and for year, two-digit-SIC and country fixed effects. The regressions exclude non-UK firms with fewer than 10 transcripts in 2015-2018, and firms in the 'Non Classifiable' sectors. Standard errors are clustered by firm. ${ }^{*}, * *$, and ${ }^{* * *}$ indicate statistical significance at the 10,5 , and 1 percent levels, respectively. 
Table 11: Timing of the Effect of Brexit Risk

\begin{tabular}{lcc}
\hline \hline & $I_{i, t} / K_{i, t-1} \cdot 100$ & $\Delta$ emp $_{i, t} /$ emp $_{i, t-1} \cdot 100$ \\
\cline { 2 - 3 } & $(1)$ & $(2)$ \\
\hline BrexitRisk $_{i, t}$ & -0.251 & $-0.509^{* *}$ \\
& $(0.156)$ & $(0.210)$ \\
BrexitRisk $_{i, t-1}$ & $-0.471^{* * *}$ & -0.172 \\
& $(0.150)$ & $(0.238)$ \\
\hline \multirow{2}{*}{$R^{2}$} & 0.072 & 0.047 \\
$\mathrm{~N}$ & 21,449 & 22,698 \\
\hline
\end{tabular}

Notes: This table reports estimates from panel regressions using yearly data. In all specifications, we control for $\log$ (assets) and for two-digit-SIC $\times$ year and country fixed effects. The regressions exclude non-UK firms with fewer than 10 transcripts in 2015-2018, and firms in the 'Non Classifiable' sectors. Standard errors are clustered by firm. $*, * *$, and $* * *$ indicate statistical significance at the 10,5 , and 1 percent levels, respectively. 


\title{
Online Appendix
}

to

\section{"The Global Impact of Brexit Uncertainty"}

by

\author{
Tarek A. Hassan, Stephan Hollander, Laurence van Lent, and Ahmed \\ Tahoun
}

Appendix Table 1: Most Frequent Synonyms for Risk or Uncertainty

\begin{tabular}{|c|c|c|c|}
\hline Word & Frequency & Word & Frequency \\
\hline uncertainty & 1,157 & prospect & 4 \\
\hline uncertainties & 260 & unsure & 3 \\
\hline risk & 205 & bet & 3 \\
\hline uncertain & 96 & insecurity & 3 \\
\hline risks & 77 & risky & 3 \\
\hline unknown & 33 & danger & 3 \\
\hline possibility & 26 & faltering & 2 \\
\hline exposed & 23 & dilemma & 2 \\
\hline instability & 20 & probability & 2 \\
\hline threat & 17 & indecision & 2 \\
\hline pending & 17 & suspicion & 2 \\
\hline doubt & 16 & hesitant & 2 \\
\hline fear & 16 & unpredictability & 2 \\
\hline unclear & 14 & unstable & 2 \\
\hline unresolved & 13 & sticky & 1 \\
\hline chance & 12 & venture & 1 \\
\hline likelihood & 7 & fluctuating & 1 \\
\hline unsettled & 6 & hesitating & 1 \\
\hline unpredictable & 6 & reservation & 1 \\
\hline variable & 5 & speculative & 1 \\
\hline
\end{tabular}

Notes: This table shows the frequency across all 85,468 earnings call transcripts between 2015q1 and 2019q1 of all single-word synonyms of "risk," "risky," "uncertain," and "uncertainty" as given in the Oxford Dictionary (excluding "question" and "questions") that appear within 10 words of "Brexit". 
Appendix Table 2: Most Frequent Positive Tone Words

\begin{tabular}{|c|c|c|c|}
\hline Word & Frequency & Word & Frequency \\
\hline despite & 250 & improvement & 23 \\
\hline good & 231 & greater & 23 \\
\hline strong & 170 & profitability & 23 \\
\hline positive & 162 & benefited & 23 \\
\hline opportunities & 99 & improving & 23 \\
\hline great & 98 & stability & 20 \\
\hline opportunity & 70 & improve & 19 \\
\hline better & 67 & optimistic & 19 \\
\hline stable & 65 & advantage & 16 \\
\hline able & 55 & favorable & 14 \\
\hline benefit & 49 & stabilize & 13 \\
\hline leading & 48 & rebound & 13 \\
\hline confident & 37 & strengthening & 12 \\
\hline progress & 35 & gain & 11 \\
\hline pleased & 33 & successful & 11 \\
\hline improved & 31 & tremendous & 11 \\
\hline gains & 29 & excellent & 11 \\
\hline stronger & 28 & successfully & 9 \\
\hline strength & 26 & achieve & 9 \\
\hline best & 24 & stabilized & 9 \\
\hline
\end{tabular}

Notes: This table shows the frequency across all 85,468 earnings call transcripts between $2015 \mathrm{q} 1$ and $2019 \mathrm{q} 1$ of all positive tone words from Loughran and McDonald (2011) (their list contains 354 positive tone words) appearing within 10 words of "Brexit." 
Appendix Table 3: Most Frequent Negative Tone Words

\begin{tabular}{|c|c|c|c|}
\hline Word & Frequency & Word & Frequency \\
\hline volatility & 297 & negatively & 40 \\
\hline concerns & 220 & slowing & 39 \\
\hline negative & 182 & adverse & 38 \\
\hline difficult & 102 & aftermath & 37 \\
\hline challenges & 99 & unexpected & 37 \\
\hline slowdown & 99 & turmoil & 35 \\
\hline decline & 85 & slower & 35 \\
\hline concerned & 85 & slowed & 32 \\
\hline concern & 84 & shutdown & 31 \\
\hline against & 74 & challenge & 31 \\
\hline weakness & 74 & crisis & 30 \\
\hline disruption & 72 & fears & 29 \\
\hline weak & 63 & delays & 26 \\
\hline weaker & 63 & weakened & 25 \\
\hline slow & 50 & problems & 25 \\
\hline late & 49 & delay & 24 \\
\hline weakening & 47 & caution & 23 \\
\hline challenging & 43 & delayed & 23 \\
\hline volatile & 43 & exposed & 23 \\
\hline fallout & 42 & recall & 22 \\
\hline
\end{tabular}

Notes: This table shows the frequency across all 85,468 earnings call transcripts between 2015q1 and 2019q1 of all negative tone words (with the exception of "question," "questions," and "ill") from Loughran and McDonald (2011) (their list contains 2,352 negative tone words) appearing within 10 words of "Brexit". 
Appendix Figure 1: Placebo Tests

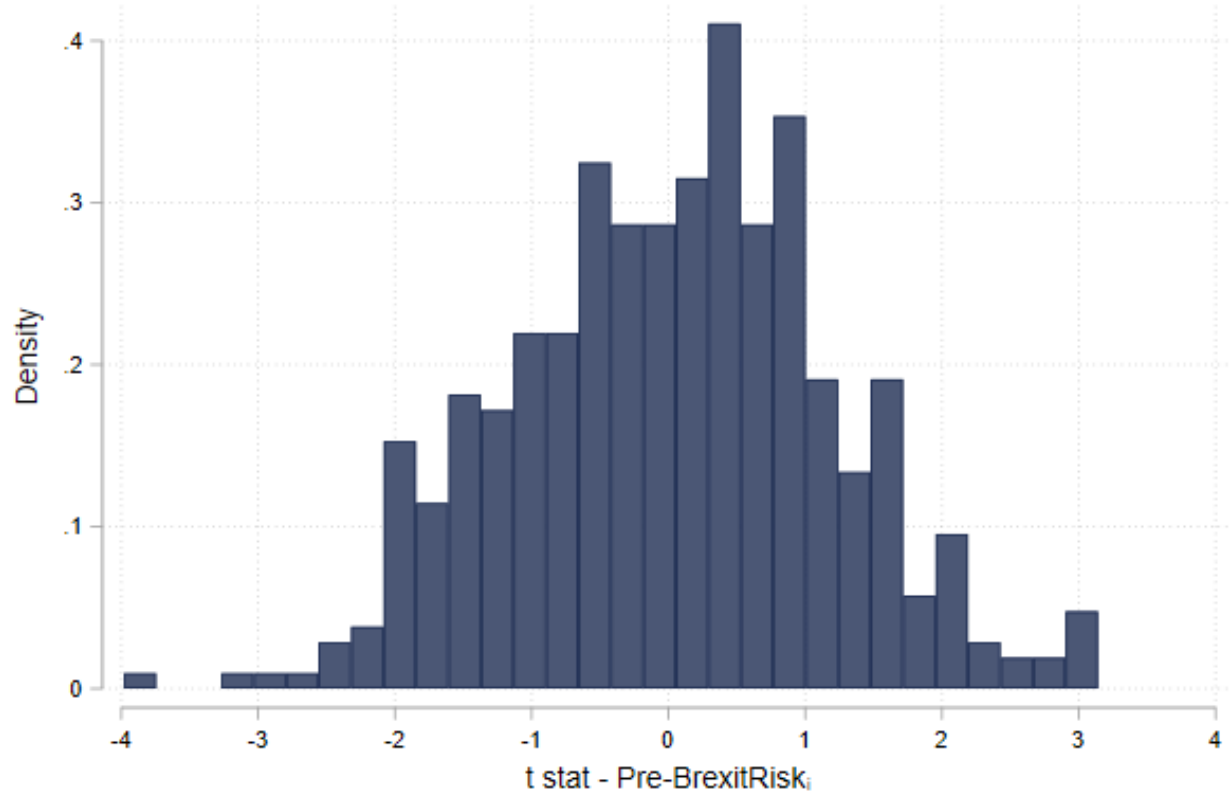

Rejection rate $(<-1.96): 3.62 \%$

Notes: As a placebo exercise, we repeat the regression specifications in Column 5 of Table 6 taking four consecutive trading days at a time from January 1, 2012 and December 31, 2015. This figure plots the distribution of the t-

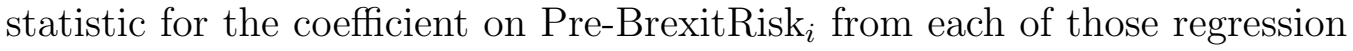
specifications. 


\section{Appendix Table 4: Brexit Risk and Estimated Average Effects by Country}

\begin{tabular}{|c|c|c|c|c|c|}
\hline \multirow[t]{2}{*}{ Country } & \multirow{2}{*}{$\begin{array}{c}\text { Mean } \\
\text { Brexit risk (s.e.) }\end{array}$} & \multirow{2}{*}{$\begin{array}{c}\text { Max } \\
\text { Brexit risk }\end{array}$} & \multirow[t]{2}{*}{$N$} & \multicolumn{2}{|c|}{ Estimated effect (\%) on } \\
\hline & & & & $I_{i, t+1} / K_{i, t}$ & $\Delta e m p_{i, t} / e m p_{i, t-1}$ \\
\hline All firms & $0.196(0.011)$ & 12.387 & 7,674 & -0.43 & -0.71 \\
\hline USA & $0.111(0.010)$ & 18.371 & 3,791 & -0.37 & -1.21 \\
\hline Ireland & $1.681(0.489)$ & 18.312 & 53 & -3.91 & -4.21 \\
\hline UK Channel Islands & $1.174(1.628)$ & 10.564 & 8 & -2.10 & -3.30 \\
\hline United Kingdom & $1.000(0.115)$ & 18.911 & 396 & -2.82 & -4.25 \\
\hline South Africa & $0.579(0.164)$ & 7.926 & 74 & -1.99 & -8.10 \\
\hline Netherlands & $0.444(0.118)$ & 5.560 & 76 & -1.18 & -2.04 \\
\hline Denmark & $0.434(0.158)$ & 5.299 & 50 & -1.57 & -1.84 \\
\hline France & $0.386(0.078)$ & 4.617 & 130 & -1.38 & -2.59 \\
\hline Belgium & $0.372(0.188)$ & 5.054 & 31 & -1.49 & -2.24 \\
\hline Switzerland & $0.326(0.099)$ & 7.673 & 98 & -1.19 & -2.79 \\
\hline Sweden & $0.322(0.109)$ & 12.592 & 147 & -0.75 & -1.18 \\
\hline Singapore & $0.314(0.145)$ & 5.565 & 41 & -0.87 & -1.82 \\
\hline Germany & $0.304(0.056)$ & 3.658 & 150 & -0.88 & -1.71 \\
\hline Spain & $0.287(0.098)$ & 3.696 & 61 & -1.21 & -2.48 \\
\hline Australia & $0.208(0.058)$ & 9.910 & 321 & -0.43 & -0.72 \\
\hline Norway & $0.205(0.124)$ & 7.506 & 68 & -0.44 & -0.65 \\
\hline Monaco & $0.202(0.202)$ & 2.021 & 10 & -0.45 & -0.30 \\
\hline Hong Kong & $0.189(0.091)$ & 4.437 & 77 & -0.55 & -0.98 \\
\hline Austria & $0.152(0.089)$ & 2.523 & 31 & -0.62 & -1.10 \\
\hline S. Korea & $0.151(0.069)$ & 1.658 & 34 & -0.28 & -2.56 \\
\hline Bermuda & $0.131(0.051)$ & 2.291 & 63 & -0.42 & -0.44 \\
\hline Canada & $0.125(0.029)$ & 6.469 & 546 & -0.25 & -0.33 \\
\hline India & $0.118(0.032)$ & 5.104 & 270 & -0.25 & -0.61 \\
\hline Finland & $0.116(0.095)$ & 4.245 & 45 & -0.48 & -2.06 \\
\hline Japan & $0.115(0.040)$ & 4.382 & 153 & -0.44 & -0.77 \\
\hline Luxembourg & $0.114(0.059)$ & 1.713 & 34 & -0.28 & -0.62 \\
\hline Italy & $0.096(0.052)$ & 3.494 & 75 & -0.37 & -0.74 \\
\hline Mexico & $0.084(0.063)$ & 4.151 & 68 & -0.28 & -0.50 \\
\hline Turkey & $0.061(0.043)$ & 0.808 & 23 & -0.49 & -0.48 \\
\hline Russia & $0.055(0.055)$ & 2.238 & 41 & -0.09 & -0.20 \\
\hline Malaysia & $0.030(0.030)$ & 0.548 & 18 & -0.09 & -0.40 \\
\hline New Zealand & $0.030(0.030)$ & 1.183 & 39 & -0.07 & -0.06 \\
\hline Chile & $0.027(0.027)$ & 0.681 & 25 & -0.12 & -0.57 \\
\hline Greece & $0.025(0.025)$ & 0.498 & 20 & -0.11 & $-0.55^{*}$ \\
\hline Poland & $0.023(0.023)$ & 0.644 & 28 & -0.07 & -0.08 \\
\hline Israel & $0.022(0.022)$ & 1.353 & 61 & -0.05 & -0.07 \\
\hline China & $0.005(0.005)$ & 0.870 & 181 & -0.00 & -0.01 \\
\hline Brazil & $0.004(0.004)$ & 0.561 & 139 & -0.01 & -0.03 \\
\hline
\end{tabular}

Notes: For the country indicated in the first column, this table shows the mean (standard error), max, number of firms, and the estimated effect on $I_{i, t+1} / K_{i, t}$ and $\Delta e m p_{i, t} / e m p_{i, t-1}$. The mean and max of Brexit risk are calculated over all firms headquartered in that country. The standard error on the mean is calculated as $\hat{\sigma} / \sqrt{N}$ where $\hat{\sigma}$ is the standard deviation of Brexit Risk. $N$ is the total number of our sample firms within a specific country. The estimated effect (\%) is calculated as $\hat{\beta}_{y} \times \overline{\text { BrexitRisk }_{i, t}} / \overline{y_{i, t}}$, where $y \in\left\{I_{i, t+1} / K_{i, t} .100, \Delta e m p_{i, t} / e m p_{i, t-1} .100\right\}$, and $\hat{\beta}_{y}$ is the estimated coefficient from Tables 8 and 10 . For Greece, the estimated effect on employment (marked by an ${ }^{*}$ ) is normalized by average employment in the panel instead of by average employment in the cross section (which is just below zero). We exclude countries for which we have fewer than five firms. 
Appendix Table 5: Brexit Sentiment by Country

\begin{tabular}{|c|c|c|c|c|}
\hline \multirow[b]{2}{*}{ Country } & \multicolumn{4}{|c|}{ Brexit Sentiment } \\
\hline & Mean (s.e.) & Min & Max & $N$ \\
\hline Ireland & $-1.386(1.056)$ & -44.593 & 8.898 & 53 \\
\hline United Kingdom & $-1.000(0.211)$ & -37.778 & 10.806 & 396 \\
\hline Germany & $-0.773(0.224)$ & -17.177 & 8.064 & 150 \\
\hline Austria & $-0.604(0.509)$ & -12.918 & 2.507 & 31 \\
\hline Norway & $-0.561(0.291)$ & -14.526 & 1.670 & 68 \\
\hline Italy & $-0.544(0.309)$ & -18.209 & 3.872 & 75 \\
\hline Denmark & $-0.494(0.299)$ & -9.236 & 5.241 & 50 \\
\hline Sweden & $-0.441(0.364)$ & -33.137 & 12.056 & 147 \\
\hline France & $-0.404(0.243)$ & -22.672 & 9.341 & 130 \\
\hline Hong Kong & $-0.403(0.243)$ & -14.837 & 5.014 & 77 \\
\hline New Zealand & $-0.392(0.264)$ & -9.267 & 0.000 & 39 \\
\hline Singapore & $-0.376(0.181)$ & -6.424 & 0.887 & 41 \\
\hline Monaco & $-0.338(0.338)$ & -3.379 & 0.000 & 10 \\
\hline Belgium & $-0.321(0.151)$ & -3.250 & 1.352 & 31 \\
\hline Chile & $-0.308(0.265)$ & -6.565 & 0.000 & 25 \\
\hline Greece & $-0.285(0.193)$ & -3.712 & 0.000 & 20 \\
\hline Luxembourg & $-0.271(0.129)$ & -3.461 & 0.000 & 34 \\
\hline Malaysia & $-0.258(0.258)$ & -4.649 & 0.000 & 18 \\
\hline Spain & $-0.241(0.148)$ & -6.095 & 2.173 & 61 \\
\hline India & $-0.210(0.108)$ & -12.173 & 15.205 & 270 \\
\hline Turkey & $-0.208(0.124)$ & -2.433 & 0.000 & 23 \\
\hline Russia & $-0.182(0.182)$ & -7.481 & 0.000 & 41 \\
\hline Finland & $-0.166(0.150)$ & -4.368 & 3.816 & 45 \\
\hline Mexico & $-0.150(0.101)$ & -5.373 & 1.084 & 68 \\
\hline Canada & $-0.140(0.049)$ & -13.691 & 9.301 & 546 \\
\hline Japan & $-0.131(0.197)$ & -25.473 & 10.767 & 153 \\
\hline South Africa & $-0.130(0.232)$ & -4.569 & 11.808 & 74 \\
\hline Switzerland & $-0.128(0.217)$ & -6.600 & 6.718 & 98 \\
\hline S. Korea & $-0.089(0.124)$ & -3.369 & 1.386 & 34 \\
\hline Netherlands & $-0.068(0.231)$ & -6.199 & 10.260 & 76 \\
\hline China & $-0.060(0.045)$ & -7.817 & 0.000 & 181 \\
\hline Bermuda & $-0.043(0.151)$ & -4.750 & 4.579 & 63 \\
\hline Brazil & $-0.032(0.025)$ & -2.449 & 1.013 & 139 \\
\hline Israel & $0.023(0.023)$ & 0.000 & 1.388 & 61 \\
\hline Poland & $0.057(0.057)$ & 0.000 & 1.607 & 28 \\
\hline Australia & $0.062(0.169)$ & -16.335 & 38.573 & 321 \\
\hline UK Channel Islands & $1.713(2.233)$ & -2.341 & 15.728 & 8 \\
\hline
\end{tabular}

Notes: For the country indicated in the first column, this table shows the mean (standard error), min, max, and the number of firms. The mean, min, and max of Brexit Sentiment are calculated over all firms headquartered in a specific country. The standard error on the mean is calculated as $\hat{\sigma} / \sqrt{N}$ where $\hat{\sigma}$ is the standard deviation of Brexit Sentiment. $N$ is the total number of our sample firms in a specific country. We exclude countries for which we have fewer than five firms. 
Appendix Table 6: BrexitRisk and BrexitSentiment and Other Firm Outcomes

\begin{tabular}{|c|c|c|c|c|c|c|}
\hline & \multicolumn{6}{|c|}{$\Delta e m p_{i, t} / e m p_{i, t-1} \cdot 100$} \\
\hline & (1) & (2) & (3) & (4) & (5) & (6) \\
\hline Panel A & & & All firms & & & \\
\hline BrexitRisk $_{i, t}$ & $\begin{array}{c}-0.487^{* * *} \\
(0.176)\end{array}$ & $\begin{array}{c}-0.495^{* * *} \\
(0.179)\end{array}$ & $\begin{array}{c}-0.391^{* *} \\
(0.179)\end{array}$ & $\begin{array}{c}-0.403^{* *} \\
(0.187)\end{array}$ & $\begin{array}{c}-0.589^{* *} \\
(0.289)\end{array}$ & $\begin{array}{c}-0.531^{* * *} \\
(0.190)\end{array}$ \\
\hline BrexitSentiment $_{i, t}$ & $\begin{array}{c}0.000 \\
(0.083)\end{array}$ & $\begin{array}{l}-0.016 \\
(0.084)\end{array}$ & $\begin{array}{l}-0.011 \\
(0.082)\end{array}$ & $\begin{array}{l}-0.024 \\
(0.084)\end{array}$ & $\begin{array}{l}-0.038 \\
(0.108)\end{array}$ & $\begin{array}{c}0.015 \\
(0.082)\end{array}$ \\
\hline Non-BrexitRisk $_{i, t}$ & & $\begin{array}{l}-0.004 \\
(0.004)\end{array}$ & $\begin{array}{c}-0.018^{* * *} \\
(0.005)\end{array}$ & $\begin{array}{c}-0.026^{* * *} \\
(0.006)\end{array}$ & $\begin{array}{c}-0.035^{* * *} \\
(0.008)\end{array}$ & $\begin{array}{c}-0.017^{* * *} \\
(0.005)\end{array}$ \\
\hline Non-BrexitSentiment ${ }_{i, t}$ & & $\begin{array}{c}0.003^{* * *} \\
(0.000)\end{array}$ & $\begin{array}{c}0.003^{* * *} \\
(0.000)\end{array}$ & $\begin{array}{c}0.003^{* * *} \\
(0.000)\end{array}$ & $\begin{array}{c}0.003^{* * *} \\
(0.001)\end{array}$ & $\begin{array}{c}0.003^{* * *} \\
(0.000)\end{array}$ \\
\hline PRiskTrade $_{i, t}$ (std.) & & & & $\begin{array}{l}-0.134 \\
(0.214)\end{array}$ & & \\
\hline Average UK sales ${ }_{i}$ (pre-Brexit) & & & & & $\begin{array}{l}-2.756 \\
(3.198)\end{array}$ & \\
\hline$\overline{\text { BrexitExposure }_{i}}$ & & & & & & $\begin{array}{c}1.158^{* *} \\
(0.493)\end{array}$ \\
\hline$R^{2}$ & 0.020 & 0.024 & 0.052 & 0.055 & 0.064 & 0.052 \\
\hline $\mathrm{N}$ & 27,156 & 27,156 & 27,141 & 26,160 & 18,326 & 27,141 \\
\hline Year FE & $\mathrm{Y}$ & $\mathrm{Y}$ & $\mathrm{Y}$ & $\mathrm{Y}$ & $\mathrm{Y}$ & $\mathrm{Y}$ \\
\hline Industry FE & $\mathrm{Y}$ & Y & $\mathrm{Y}$ & Y & $\mathrm{Y}$ & Y \\
\hline Industry x Year FE & $\mathrm{N}$ & $\mathrm{N}$ & $\mathrm{Y}$ & Y & $\mathrm{Y}$ & $\mathrm{Y}$ \\
\hline Country FE & $\mathrm{N}$ & $\mathrm{N}$ & $\mathrm{Y}$ & $\mathrm{Y}$ & Y & $\mathrm{Y}$ \\
\hline PANEL B & & & US firms & & & \\
\hline BrexitRisk $_{i, t}$ & $\begin{array}{c}-1.277^{* * *} \\
(0.442) \\
\end{array}$ & $\begin{array}{c}-1.211^{* * *} \\
(0.430) \\
\end{array}$ & $\begin{array}{c}-1.272^{* * *} \\
(0.460) \\
\end{array}$ & $\begin{array}{c}-1.238^{* * *} \\
(0.463) \\
\end{array}$ & $\begin{array}{c}-0.952^{* * *} \\
(0.335) \\
\end{array}$ & $\begin{array}{c}-1.423^{* * *} \\
(0.488)\end{array}$ \\
\hline$R^{2}$ & 0.022 & 0.027 & 0.057 & 0.059 & 0.060 & 0.057 \\
\hline $\mathrm{N}$ & 18,117 & 18,117 & 18,099 & 17,817 & 14,856 & 18,099 \\
\hline Year FE & $\mathrm{Y}$ & $\mathrm{Y}$ & Y & Y & $\mathrm{Y}$ & Y \\
\hline Industry FE & $\mathrm{Y}$ & $\mathrm{Y}$ & $\mathrm{Y}$ & $\mathrm{Y}$ & $\mathrm{Y}$ & $\mathrm{Y}$ \\
\hline Industry x Year FE & $\mathrm{N}$ & $\mathrm{N}$ & Y & Y & $\mathrm{Y}$ & Y \\
\hline
\end{tabular}

Notes: This table reports results from regressions of $\Delta e m p_{i, t} / e m p_{i, t-1} \cdot 100$ on BrexitRisk $k_{i, t}$ and BrexitSentiment $_{i, t}$ using yearly data. Panel A uses the sample of all firms, while Panel B restricts the analysis to firms headquartered in the US. The dependent variable is winsorized at the 1st and 99th percentile. All right-hand side variables are defined as in Table 9. All regressions control for $\log$ (assets) and for and year, two-digit-SIC, and country fixed effects. The regressions exclude non-UK firms with fewer than 10 transcripts in 2015-2018, and firms in the 'Non Classifiable' sector. Standard errors are clustered by firm. *,**,*** indicate statistical significance at the 10,5 , and 1 percent levels, respectively. 
Appendix Table 7: BrexitRisk and BrexitSentiment and Other Firm Outcomes

\begin{tabular}{|c|c|c|c|c|c|c|}
\hline & \multicolumn{6}{|c|}{$\Delta$ sales $_{i, t} /$ sales $_{i, t-1} \cdot 100$} \\
\hline & (1) & $(2)$ & (3) & (4) & (5) & (6) \\
\hline Panel A & & & All firms & & & \\
\hline BrexitRisk $_{i, t}$ & $\begin{array}{l}-0.377 \\
(0.251)\end{array}$ & $\begin{array}{l}-0.396 \\
(0.253)\end{array}$ & $\begin{array}{l}-0.135 \\
(0.251)\end{array}$ & $\begin{array}{l}-0.049 \\
(0.262)\end{array}$ & $\begin{array}{l}-0.574 \\
(0.394)\end{array}$ & $\begin{array}{l}-0.243 \\
(0.272)\end{array}$ \\
\hline BrexitSentiment $_{i, t}$ & $\begin{array}{l}0.136^{*} \\
(0.074)\end{array}$ & $\begin{array}{c}0.118 \\
(0.075)\end{array}$ & $\begin{array}{l}0.135^{*} \\
(0.081)\end{array}$ & $\begin{array}{c}0.130 \\
(0.082)\end{array}$ & $\begin{array}{c}0.135 \\
(0.129)\end{array}$ & $\begin{array}{c}0.153^{*} \\
(0.079)\end{array}$ \\
\hline Non-BrexitRisk $_{i, t}$ & & $\begin{array}{c}0.014 \\
(0.009)\end{array}$ & $\begin{array}{l}-0.000 \\
(0.010)\end{array}$ & $\begin{array}{l}-0.006 \\
(0.013)\end{array}$ & $\begin{array}{l}-0.023 \\
(0.017)\end{array}$ & $\begin{array}{l}-0.000 \\
(0.010)\end{array}$ \\
\hline Non-BrexitSentiment $_{i, t}$ & & $\begin{array}{c}0.004^{* * *} \\
(0.001)\end{array}$ & $\begin{array}{c}0.004^{* * *} \\
(0.001)\end{array}$ & $\begin{array}{c}0.004^{* * *} \\
(0.001)\end{array}$ & $\begin{array}{c}0.005^{* * *} \\
(0.001)\end{array}$ & $\begin{array}{c}0.004^{* * *} \\
(0.001)\end{array}$ \\
\hline PRiskTrade $_{i, t}$ (std.) & & & & $\begin{array}{c}-0.698^{* *} \\
(0.324)\end{array}$ & & \\
\hline Average UK sales $i$ (pre-Brexit) & & & & & $\begin{array}{l}-3.111 \\
(8.740)\end{array}$ & \\
\hline$\overline{\text { BrexitExposure }_{i}}$ & & & & & & $\begin{array}{c}0.841 \\
(0.824) \\
\end{array}$ \\
\hline$R^{2}$ & 0.024 & 0.025 & 0.052 & 0.054 & 0.061 & 0.052 \\
\hline $\mathrm{N}$ & 29,059 & 29,059 & 29,042 & 27,890 & 18,967 & 29,042 \\
\hline Year FE & $\mathrm{Y}$ & $\mathrm{Y}$ & Y & Y & Y & Y \\
\hline Industry FE & $\mathrm{Y}$ & $\mathrm{Y}$ & $\mathrm{Y}$ & $\mathrm{Y}$ & Y & $\mathrm{Y}$ \\
\hline Industry x Year FE & $\mathrm{N}$ & $\mathrm{N}$ & Y & Y & Y & Y \\
\hline Country FE & $\mathrm{N}$ & $\mathrm{N}$ & Y & $\mathrm{Y}$ & $\mathrm{Y}$ & $\mathrm{Y}$ \\
\hline PANEL B & & & US firms & & & \\
\hline BrexitSentiment $_{i, t}$ & $\begin{array}{c}0.346^{* *} \\
(0.140) \\
\end{array}$ & $\begin{array}{c}0.305^{* *} \\
(0.142)\end{array}$ & $\begin{array}{c}0.410^{* *} \\
(0.167)\end{array}$ & $\begin{array}{c}0.383^{* *} \\
(0.164) \\
\end{array}$ & $\begin{array}{l}0.295^{*} \\
(0.158)\end{array}$ & $\begin{array}{c}0.422^{* *} \\
(0.166)\end{array}$ \\
\hline$R^{2}$ & 0.034 & 0.035 & 0.058 & 0.060 & 0.061 & 0.058 \\
\hline $\mathrm{N}$ & 18,846 & 18,846 & 18,828 & 18,532 & 15,371 & 18,828 \\
\hline Year FE & $\mathrm{Y}$ & Y & Y & Y & Y & $\mathrm{Y}$ \\
\hline Industry FE & $\mathrm{Y}$ & $\mathrm{Y}$ & $\mathrm{Y}$ & Y & $\mathrm{Y}$ & $\mathrm{Y}$ \\
\hline Industry x Year FE & $\mathrm{N}$ & $\mathrm{N}$ & $\mathrm{Y}$ & $\mathrm{Y}$ & $\mathrm{Y}$ & $\mathrm{Y}$ \\
\hline
\end{tabular}

Notes: This table reports results from regressions of $\Delta$ sales $_{i, t} /$ sales $_{i, t-1} \cdot 100$ on BrexitRisk B $_{i, t}$ and BrexitSentiment $_{i, t}$ using yearly data. The dependent variable is winsorized at the 1st and 99th percentile. All right-hand side variables are defined as in Table 9. All regressions control for $\log$ (assets) and for and year, two-digit-SIC, and country fixed effects. The regressions exclude nonUK firms with fewer than 10 transcripts in 2015-2018, and firms in the 'Non Classifiable' sector. Standard errors are clustered by firm. ${ }^{*}, * *, * * *$ indicate statistical significance at the 10,5 , and 1 percent levels, respectively. 
Appendix Table 8: Distribution of Sample Firms across Districts in UK

\begin{tabular}{cc}
\hline \hline Number of counties & Number of firms \\
\hline 54 & 1 \\
26 & 2 \\
14 & 3 \\
7 & 4 \\
5 & 5 \\
3 & 6 \\
3 & 7 \\
1 & 8 \\
1 & 10 \\
1 & 54 \\
1 & 90 \\
\hline
\end{tabular}

Notes: This table shows the number of UK districts (left column) with the number of UK firms in our sample that headquartered in that district (right column). 